\title{
Research Paper \\ Comparison of the Effectiveness of Acceptance and Commitment Therapy and Guided Imagery on the Resilience of Cardiac Disease Patients Referring to the Heart Rehabilitation Department
}

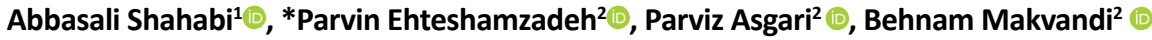

1. Department of Health Psychology, Khorramshahr -Persian Gulf International Branch, Islamic Azad University, Khorramshahr, Iran.

2. Department of Psychology, Ahvaz Branch, Islamic Azad University, Ahvaz, Iran.

\begin{tabular}{|c|c|}
\hline $\begin{array}{l}\text { Use your device to scan } \\
\text { and read the article online }\end{array}$ & \\
\hline 口ifing & $\begin{array}{l}\text { CHtation Shahabi A, Ehteshamzadeh P, Asgari P, Makvandi B. [Comparison of the Effectiveness of Acceptance and Commitment } \\
\text { Therapy and Guided Imagery on the Resilience of Cardiac Disease Patients Referring to the Heart Rehabilitation Department } \\
\text { (Persian)]. Quarterly of "The Horizon of Medical Sciences". 2020; 26(3):276-297. https://doi.org/10.32598/hms.26.3.3184.1 } \\
\text { doi https://doi.org/10.32598/hms.26.3.3184.1 }\end{array}$ \\
\hline
\end{tabular}

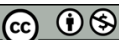

Received: 27 Jun 2019 Accepted: 15 Feb 2020 Available Online: $01 \mathrm{Jul} 2020$

Key words: ACT, GMI, Resilience, Heart diseases

\section{A B S T R A C T}

Aims One of the most essential causes of mortality in the world is cardiovascular disease. Biological backgrounds and physical risk factors, types of stress and distress, ineffective interaction strategies, stressful life events, as well as low levels resiliency contribute to the start and severity of the disease are some features of this disease. The present research tends to compare the effectiveness of Acceptance and Commitment Therapy (ACT) and Guided Mental Imagery (GSI) on the resiliency in cardiovascular patients referring to cardiac rehabilitation ward through 2018-2019.

Methods \& Materials This study is a quasi-experimental with pretest-posttest and follow-up with control group. The research samples were 45 participants selected using available method and completed the Conner-Davidson Resiliency Scale (CD-RIS). Interventions consisted of 8 sessions of 60 minutes each (ACT group) and 10 sessions of 45 minutes each (GSI group). Data analysis was performed using repeated measurement covariance analysis and Bonferroni test in SPSS V. 22 software.

Findings The research findings showed the effectiveness of the two treatments of ACT and GSI on the increase in resiliency of cardiovascular patients. In other words, the results of Bonferroni test indicate the more effectiveness of ACT than GSI in increasing resiliency is in cardiovascular patients $(P<0.005)$. Therefore, it can be concluded that ACT, by focusing on psychological flexibility, is more effective than GSI on Resilience.

Conclusion According to the results of this study, the ACT with the main acceptance factor, may expand the concept of acceptance by believing in lack of control over life in cardiovascular patients, and increase their resiliency. A one-month follow-up of the results showed its sustainability and strength.

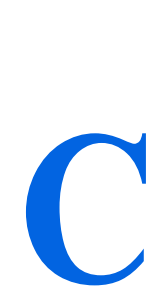

\section{Extended Abstract}

\section{Introduction}

hronic diseases are among the most common causes of death in the world. They persist for a long time and affect a per- son's normal functions. Chronic disease is a serious health challenge that lasts for at least three months and requires hospitalization, home care, and medical care. Cardiac disease is among chronic diseases, which is the most common cause of death and is an important factor for disability and premature death [2].

\section{* Corresponding Author:}

Parvin Ehteshamzadeh, PhD.

Address: Department of Psychology, Ahvaz Branch, Islamic Azad University, Ahvaz, Iran.

Tel: +98 (61) 33348336

E-mail: ehtesham@iauahvaz.ac.ir 
Cardiovascular disease is one of the most common diseases in developed countries and is increasing rapidly in developing countries [3]. According to the latest study by the Ministry of Health and Medical Education of Iran, cardiovascular diseases are the leading cause of death in the country accounting for 378 deaths daily in Iran. It is estimated that by 2020 , a total of 25 million people will die each year due to cardiac disease [3].

Psychological factors, such as defense mechanisms and maladaptive coping methods, stress, anxiety, depression, temperamental and communication disorders, aggression, generalized anxiety disorder, interpersonal hostility, obsessive-compulsive thoughts and behaviors, phobia, personality traits, and different types of psychological injuries play a role in both development and aggravation of cardiac disease [4].

Heart failure causes many symptoms leading to patients' intolerance to several activities and changes in their lifestyle, which affect their tolerance and resilience [5]. Resilience is the ability of a person to adapt successfully to life-threatening conditions and stressors and is a form of self-healing that has positive emotional, affective, and cognitive results $[6,7]$. Resilience does not simply mean that an individual is resilient to harm or threatening conditions, but he must actively and constructively participate in the environment [8]. People with high resilience have a lower level of avoidance and cope with the pain and suffering, and do not consider their disease to be catastrophic $[9,10]$.

Resilience has attracted the attention of many researchers over the past ten years. This factor is one of the psychological characteristics that is very important in health [11]. Resilient people are dynamic and flexible to deal with living conditions [6]. Psychological resilience is defined as the ability to overcome difficulties and life situations. From Newman's point of view, psychological resilience has been mentioned as the ability to adapt to adversity. Resilience is not only increasing a person's tolerance and adaptability to dealing with a problem but also considers maintaining mental health and promoting it [12].

Werner considers resiliency as a factor to change the negative consequences positively and maintain good health. In terms of the consequences of resilience, Jokar et al. in their research showed that resilience predicts a significant level of mental health and satisfaction. That is, increasing resilience leads to a reduction in emotional problems and stress, resulting in an increase in the level of an individual's satisfaction [13].
Acceptance and Commitment Therapy (ACT) is one of the newest therapies for third-wave psychology, which its effectiveness has been confirmed in many chronic diseases. ACT is a form of clinical psychology and is committed to providing scientific treatment methods [14]. ACT does not cause a direct change in clients, but it helps them connect with their experiences in different ways and be able to fully engage with a meaningful, value-based life. ACT is rooted in a philosophical theory called functional contextualism and is based on the Relational Frame Theory (RFT), which is a research program on language and cognition [15].

The goal of this treatment is to increase psychological and behavioral flexibility in areas where Experiential Avoidance (EA) prevails and deprives the individual of basic life. Psychological flexibility increases a person's ability to choose an action that is more appropriate among various options. It is also the ability to fully communicate with the present and change or maintain the behavior to achieve valuable and important life goals [16]. Psychological flexibility in the ACT is achieved through six main processes: acceptance, detachment, self as context, being present, valuing, and committed action [17].

Recent studies on ACT have shown its efffectiveness for the treatment of depression [18], post-traumatic stress disorder [19], panic disorder [20], chronic pain [8], obsessive-compulsive disorder [23], breast cancer [24], multiple sclerosis [25], diabetes [26, 27], abnormal grief [28], and reducing job stress [22].

Hoffman et al. found that multiple therapeutic approaches, such as psychological interventions, had far shorter and longer-term effects on pain and improved daily and occupational functioning in individuals [29]. By examining acceptance-based interventions, such as ACT in patients with chronic pain, Viehoff et al. reported that although the abovementioned new approaches were not more effective than the cognitive-behavioral approach, they were relatively effective and could be considered as alternative therapies [30]. Regarding the effectiveness of ACT in patients with chronic pain, Wells and McCracken showed that after implementing the treatment plan, factors, such as the level of the pain experience, depression, anxiety, disability, handicap, job status, and physical function significantly improved in patients compared with the pre-treatment stage [31]. Regarding the role of ACT in reducing the depression of type 2 diabetic patients, Hor et al. examined 30 patients and showed that this therapeutic method was effective in reducing their depression with a stable effect in the follow-up period [32]. 
The Guided Subjective Imagery (GSI) is another treatment for chronic diseases. GSI, as a mind-body technique, is based on the idea that mind and body are interconnected and can affect and strengthen each other in the treatment of diseases and creating health. Imaging activates the same area of the brain that is activated during the experience of a real event; that is, the individual creates precisely a stream of thought, in which he/she can see, hear, feel, or smell what he/she desires to feel at that time and also to visualize it in his/her imagination. In addition, guided imagery is a strategy that creates a sense of power and relaxation by emphasizing and use of images, landscapes, sounds, music, and words. In imaging, people are encouraged to take deep abdominal and diaphragmatic breaths, and then release the muscles and imagine landscapes, such as forests, the beach, and holy places, and pay attention to the surrounding sounds and smells. Studies have shown that focusing on visualization and positive thinking can lead to comfort and mood balance. Visualization reduces pain, tension, anxiety, and depression by creating a competitive focus and increases the feeling of well-being [35].

Saedi and Abolghasemi showed that mental imaging and gradual stress relief, along with biofeedback, are more effective and stable than drug therapy in reducing migraine headaches. It has shown that visualization is a pain management technique for the treatment of arthritis, fibromyalgia, cancer, headaches, acute coronary heart syndrome [28], acute and chronic pain, and other medical conditions [36]. In a study conducted to investigate the effect of sedation methods on the anxiety of patients with a heart attack in Tehran, the results showed that all three methods of indoctrination, visualization and speaking were effective in reducing patients' anxiety, but speaking was more effective than the others [37]. In another study aimed at implementing a guided imagery program for patients undergoing heart surgery and its effects on anxiety levels, pain, duration of disease, hospital costs, and patient satisfaction, guided imagery reduced all these factors [28].

this research was conducted due to the increasing number of people with cardiovascular diseases and postoperative complications or other interventions, as well as considering the importance of psychological issues in the rehabilitation of these patients and the development of effective psychological therapies in chronic diseases, such as cardiac disease. We used two psychological therapies: 1. "ACT" that has contributed to the increased cognitive flexibility, tolerance, and resilience, and is helpful to improve the lives of these patients; 2. "guided imagery" that has had positive and significant effects on anxiety, pain, duration of illness, and hospital costs for chronic diseases. These two methods should be compared to better understand the effectiveness of them. No study has yet examined the effectiveness of ACT and guided imagery methods on the resilience of cardiovascular patients. Therefore, in this study aimed at investigating the effectiveness of ACT and guided imagery on the resilience of cardiac patients referring to the cardiac rehabilitation department and comparing these two methods.

\section{Materials and Methods}

This clinical trial (IRCT20190727044345N1) with Pretest-Post-test design and follow-up and a control group was performed on cardiovascular patients referred to the cardiac rehabilitation department of Imam Reza Hospital, Mashhad in 2018. Samples were selected by the availability sampling method and random drawing and assigned to three groups (two experimental and one control). According to Borg et al. 15 people are sufficient for the sample size in each group in experimental and semi-experimental studies [38]. Based on a clinical interview, 45 cardiovascular patients were selected using the DSM-V criteria. Inclusion criteria were hospital admission for a heart problem in the cardiac rehabilitation department, consent of the patient to participate in the research, minimum literacy (secondary school) to understand the concepts of the treatment, the age range of 35 - 75 years, lack of other physical diseases, lack of severe mental illness, neurological disorders, such as epilepsy and Alzheimer's disease, drug and alcohol addiction, and the approval of the treating physician on the feasibility of the patient's participation in the study. Exclusion criteria were the patient's dissatisfaction with continuing the research, concomitant use of psychedelics, arrhythmia and initiation of treatment, and conducting cardiopulmonary resuscitation during the intervention.

The research protocol was approved by the university's Ethics Committee, registered at the Iranian Clinical Trial Database, and obtained permission from the officials of Imam Reza Hospital. The patients signed the informed consent form and were explained about the purpose of the study. After obtaining written consent, the demographic information form and the Connor-Davidson resilience questionnaire were completed. The intervention for the guided imagery group (10 sessions) was performed using the Nozari training package (quoted by Alifar and Nokani, 2013) [39]. Patients received two 45-min sessions per week (4 initial sessions on negative beliefs, thoughts, and ideas) and in the next 6 sessions (between 10 a.m. and 12 p.m.) in the cardiac rehabilitation department using a laptop and an audio player, they listened to a mental imagery file prepared by the researcher. To control the interfering factors and to use the audio file accurately, the researcher attended all the meetings. The intervention for the ACT group (8 sessions) was performed using the Hayes and Strosahl (2002) treatment package, quoted by Khamseh (2017) [40]. 
Table 1. A summary of the Guided Subjective Imagery (GSI) training sessions

\begin{tabular}{|c|c|}
\hline Session & Interventions / Content \\
\hline First & $\begin{array}{l}\text { The subjects were introduced to each other, the plan and objectives of the research were discussed, and the subjects were } \\
\text { justified. }\end{array}$ \\
\hline Second & The subjects were informed to identify their misconceptions and irrational thoughts. \\
\hline Third & $\begin{array}{l}\text { The session began with explanations about the fact that negative thoughts, beliefs, and perceptions are the basis for the } \\
\text { emotional disorder, decreased levels of resilience, and misperceptions about the disease. Also, guided imagery techniques } \\
\text { and their steps were taught to the patients. }\end{array}$ \\
\hline Fourth & The patients were taught how to deal with negative thoughts and ideas. \\
\hline $\begin{array}{l}\text { Fifth to } \\
\text { tenth }\end{array}$ & $\begin{array}{l}\text { The subjects were taught to immerse themselves in relaxing imageries and perform the steps of guided imagery in three } 15- \\
\text { min sessions. } \\
\text { Step-by-step guide for mental imagery: Relax for a few minutes ... Take off your shoes, put on comfortable clothes, close your } \\
\text { eyes, and take a few deep breaths. Imagine walking down a staircase. In each step, pay attention to the feeling that makes you } \\
\text { more and more relaxed ... When you are completely relaxed, visualize a favorite scene ... When you feel comfortable in your } \\
\text { desired scene, gradually turn your mind to the problem you want to solve ... If multiple images come to your mind, choose } \\
\text { one of them to consider in the current session ... If no image comes to your mind, try turning to another sense ... Imagine that } \\
\text { your problem will be completely resolved at the end of the session. This creates the initial healing plan inside you. At the end } \\
\text { of the session, take a few more deep breaths and imagine yourself climbing an imaginary staircase ... while gradually becom- } \\
\text { ing aware of the environment, open your eyes ... stretch your body, smile, and carry on your routine activities. }\end{array}$ \\
\hline
\end{tabular}

Quarterly of

The Horizon of Medical Sciences

The patients were trained two sessions a week for $60 \mathrm{~min}$ ( 8 to 9 a.m.) by the researcher. The control group did not receive any treatment. They only did the exercises of the rehabilitation department under the supervision of the treating physician, and at the end of the sessions, they only completed the resilience questionnaire again. All sessions were performed in groups and only two participants were unable to attend 2 sessions due to their physical condition; therefore, four individual sessions were performed for them. It should be noted that these two subjects were in the ACT experimental group. The data collection tools in this study were as follows (Table $1 \&$ Table 2).

\section{Personal data sheet}

The personal data sheet was used to collect the test subjects' information regularly, including age, gender, education, marital status, history of cardiac surgery, the time of the first arrhythmia, used medications, treating physician, treatment received, and duration of the disease.

\section{Connor-Davidson Resilience Scales}

The Connor-Davidson Resilience Scale (CD-RISC) is a 25-item tool that measures the construct of resilience on a 5-point Likert scale from zero to four. The minimum resilience score on this scale is zero and the maximum score is 100. The results of a preliminary study on the psychometric properties of this scale confirmed its reliability and validity. According to the reports, internal consistency, retest reliability, and convergent and divergent validity of the scale were appropriate [40]. The psychometric properties of the
CD-RISC (in the Persian language) have been investigated and confirmed in several studies conducted between 2005 and 2010 on patients $(n=275)$ and normal $(n=1123)$ samples [41]. In these studies, Cronbach's alpha coefficients of each subscale ranged from 0.73 to 0.91 and from 0.81 to 0.93 for the whole scale.

Data were analyzed using SPSS V. 23 software and Levene's test (to ensure homogeneity of the variances), Kolmogorov -Smirnov test (to ensure normality of the data), repeated measures ANCOVA (to measure the resilience), and Bonferroni post-hoc test (to compare the effectiveness of the two intervention methods).

\section{Results}

In the present study, the mean age of the ACT, GSI, and control groups were 54.07 $\pm 7.01,55 \pm 9.47$, and $57.93 \pm$ 8.63 years, respectively. The gender frequency of the subjects was as follows: ACT group (8 males, 53.3\%, and 7 females, 46.7\%), GSI group (14 males, 93.3\%, and 1 female, 6.7\%), and the control group (12 males, $80 \%$ and 3 females, 20\%). In all three groups, the highest level of education was diploma: ACT group (8 people, 53.3\%), GSI group (5 people, $33.3 \%$ ), and control group (11 people, $73.3 \%$ ). The marital status of these three groups was as follows: ACT group (12 married people, $80 \%$; one widow, $6.7 \%$; and 2 single, $13.3 \%$ ), GSI group (12 married, $80 \%$; and 2 divorced, $20 \%$ ), control group (10 married, 66.7\%; two single, $13.3 \%$; and 3 widows, $20 \%$ ). 
Table 2. A summary of the ACT sessions

Sessions

Pre-

First
Interventions / Content

Getting acquainted with the authorities and establishing a proper relationship with the aim of filling out the questionnaires correctly and building trust; implementing a demographic questionnaire, filling the consent form, and implementing the pre-test.

Introducing the therapist; introducing the members of the group to each other and establishing a therapeutic relationship; introducing ACT, its main goals and dimensions; determining the rules governing treatment sessions; providing information about cardiac patients and their categories; reviewing treatments for cardiac patients, their costs, and benefits; having a break; having some refreshments; assigning homework.

Reviewing previous session experiences and receiving feedback from the patients; discussing experiences and evaluating them; assessing the person's willingness to change; ACT review on creative disability; having a break and some refreshments; summarizing the discussions raised in the meeting, and assigning homework.

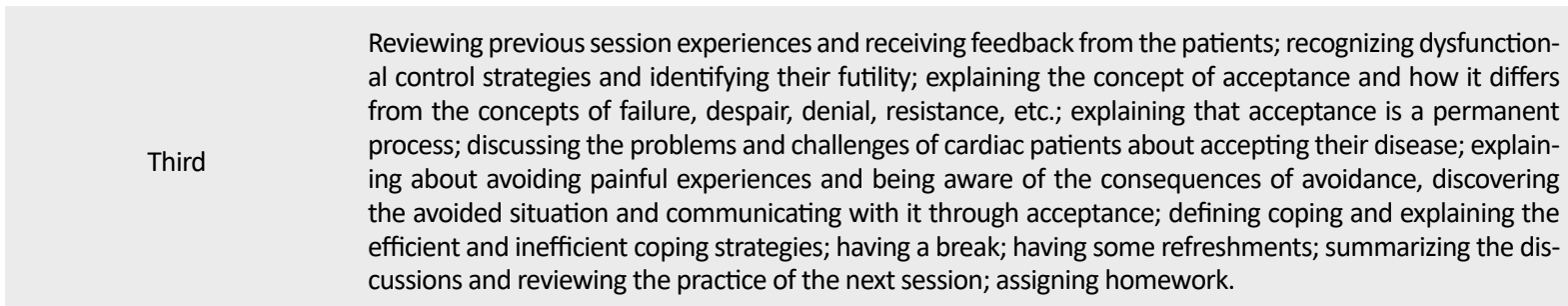

reviewing previous session experiences and receiving feedback from the patients; discussing behavioral obligation and commitment; introducing and explaining about the fusion of self-conceptualization Fourth and detachment; applying cognitive detachment techniques; intervening with the performance of problematic chains of language and metaphors; minimize wasting time with thoughts and emotions; having a break; having some refreshments; summarizing the discussions and reviewing the practice of the next session; assigning homework.

Reviewing previous session experiences and receiving feedback from the patients; demonstrating separation between self, inner experiences, and behavior; considering oneself as a context; weakening of selfconceptualization and self-expression (explaining the concepts of the role and background, considering oneself as a context and making contact with oneself using allegory, awareness of different sensory perceptions, and separation from senses that are part of mental content). In these exercises, participants learn to focus on their activities (such as breathing, walking, etc.) and to always be aware of their condition and no judgment when processing emotions, feelings, and cognitions. That is, they learn to pay attention to their thoughts and feelings and no stick to their content; having a break; having some refreshments; summarizing the discussions and reviewing the practice of the next session; assigning homework.

Reviewing previous session experiences and receiving feedback from the patients; identifying the values of patients' lives and specifying and focusing on these values and paying attention to their decision-making skill; using mindfulness techniques with an emphasis on the present; having a break; having some refreshments; summarizing the discussions and reviewing the practice of the next session; assigning homework.

Reviewing previous session experiences and receiving feedback from the patients; examining the values of the individual and deepening previous concepts; explaining the differences between values, goals, and common mistakes in value selection; discussing possible internal and external barriers to pursue values; listing the most important values and possible barriers to follow-up by the members and sharing them with the other members; discussing objectives related to values and characteristics of the (specific, measurable, realistic, and aligned with personal values) goals. identifying three of the most important values by the members and setting goals that they wanted to pursue; identifying the tasks/behaviors they intended to pursue to achieve those goals; demonstrating the risks of focusing on results.

Understanding the nature of desire and commitment (teaching about commitment to action); identifying behavioral plans according to the values and making a commitment to act on them; explaining some points concerning the concept of recurrence and readiness to deal with it; reviewing assignments and summarizing meetings; sharing the experiences of the members of the group with each other and the achievements and expectations that were not met; thanking the patients for participating in the group; performing the post-test. 
Table 3. Mean $\pm \mathrm{SD}$ of three times measurements of resilience scores in the experimental and control groups

\begin{tabular}{|c|c|c|c|c|c|}
\hline \multirow{2}{*}{ Variable } & \multirow{2}{*}{ Group } & \multirow{2}{*}{ Number } & \multicolumn{3}{|c|}{ Mean $\pm S D$} \\
\hline & & & Pre-test & Post-test & Follow-up \\
\hline \multirow{5}{*}{ Resilience } & ACT & 15 & $31.47 \pm 3.96$ & $67.27 \pm 5.45$ & $65.47 \pm 5.42$ \\
\hline & Guided imagery & 15 & $30.87 \pm 2.87$ & $61.13 \pm 6.17$ & $56.40 \pm 4.54$ \\
\hline & & & & & \\
\hline & Control & 15 & $32.73 \pm 2.73$ & $33.0 \pm 3.83$ & $31.33 \pm 4.16$ \\
\hline & Total & 45 & $31.69 \pm 3.26$ & $53.8 \pm 15.93$ & $51.07 \pm 15.31$ \\
\hline
\end{tabular}

Table 4. Results of between-subjects and within-subjects repeated measures ANCOVA of the resilience scores

\begin{tabular}{|c|c|c|c|c|c|c|c|c|}
\hline \multirow{2}{*}{ Scale } & \multirow{2}{*}{$\begin{array}{c}\text { Source of } \\
\text { Effect }\end{array}$} & \multirow{2}{*}{$\begin{array}{l}\text { Sum of } \\
\text { Squares }\end{array}$} & \multirow{2}{*}{$\begin{array}{l}\text { Degree of } \\
\text { Freedom }\end{array}$} & \multirow{2}{*}{$\begin{array}{c}\text { Mean } \\
\text { Squares }\end{array}$} & \multirow{2}{*}{$\mathbf{F}$} & \multirow{2}{*}{ Significance } & \multicolumn{2}{|c|}{ Eta Squared } \\
\hline & & & & & & & GSI & ACT \\
\hline \multirow{3}{*}{ Resilience } & Level & 29.279711 & 1 & 29.279711 & 89.8665 & 0.001 & 0.82 & 0.88 \\
\hline & Group & 39.12319 & 2 & 69.6159 & 83.190 & 0.001 & & \\
\hline & Error & 64.1355 & 42 & 32.277 & & & & \\
\hline
\end{tabular}

Table 5. Bonferroni post-hoc test results for comparison of resilience scale in the three groups

\begin{tabular}{|c|c|c|c|c|}
\hline Group & Compared to the Group & Levels & Mean Difference & Significance Level \\
\hline \multirow{2}{*}{$\begin{array}{l}\text { Acceptance and commit- } \\
\text { ment therapy }\end{array}$} & Control & & -1.26 & 0.87 \\
\hline & Guided imagery & Pre-test & 0.6 & 1.0 \\
\hline Guided imagery & Control & & -1.86 & 0.36 \\
\hline \multirow{2}{*}{$\begin{array}{l}\text { Acceptance and commit- } \\
\text { ment therapy }\end{array}$} & Control & & $34.26^{*}$ & 0.001 \\
\hline & Guided imagery & Post-test & $6.13^{*}$ & 0.008 \\
\hline Guided imagery & Control & & $28.13^{*}$ & 0.001 \\
\hline \multirow{2}{*}{$\begin{array}{l}\text { Acceptance and commit- } \\
\text { ment therapy }\end{array}$} & Control & & $34.13^{*}$ & 0.001 \\
\hline & Guided imagery & Follow-up & $9.067^{*}$ & 0.001 \\
\hline Guided imagery & Control & & $25.06^{*}$ & 0.001 \\
\hline
\end{tabular}

$* \mathrm{P}<0.05$

The results of Table 3 showed that the mean resilience score in the experimental groups (ACT and GSI) and the control group in three stages was significantly different.

According to the results of the Box's M test to check the equality of covariance matrices and considering the value
Quarterly of

The Horizon of Medical Sciences

of $\mathrm{F}$, the null hypothesis was rejected; that is, the covariance matrices observed between different groups were equal (Box's M=19.49, F=1.45, $\mathrm{P}<0.01$ ). Also, based on the Levene's test results on the equality of error variances, the assumption of the equality of variances was confirmed and the error variance of the dependent variables in all groups 
was equal $(\mathrm{F}=0.35,0.21,0.63)$. Mauchly's sphericity test also showed that the compound symmetry was acceptable. In other words, there was a significant difference between resilience scores (of pre-test, post-test, and follow-up) among the ACT, GSI, and control groups $(\mathrm{P}<0.001)$. These results indicate the effectiveness of the ACT and guided imagery on the resilience of cardiac patients. Also, the higher resilience score in the ACT experimental group compared with the GSI group indicates greater effectiveness of this treatment. Therefore, the resilience level of cardiac patients participating in these two therapeutic groups increased significantly (Table 4).

The results of the Bonferroni post-hoc test showed that the scores of the resilience variable in both experimental groups in the post-test stage increased significantly compared with the control group. In other words, the ACT had a greater effect on increasing the resilience level of cardiac patients in post-test and follow-up $(34.26,34.13)$ than the guided imagery $(28.13,25.06)$. This means that changes in the ACT experimental group were more effective and sustainable. Also, the eta-squared values indicated greater effectiveness of ACT treatment than GSI (Table 5).

\section{Discussion}

The aim of this study was to compare the effectiveness of the ACT and guided imagery methods on the resilience of cardiac patients referred to the cardiac rehabilitation department in Mashhad City. The results of the study showed that ACT-based intervention was effective in increasing the resilience level of cardiac patients.

Our results were compatible with the research of Molina et al. [42], Ghorbani et al. [43], Qomian and Shayeri [44], Rahimian Booger [45], Saeed Nouri, Akbari and Salari [12], Besharat and Ramesh [41], Momeni et al. [46], Fazeli Kebria et al. [47], Doostdar Tusi and Golshani [48].

Regarding the effectiveness of the ACT, it should be noted that this type of therapy aimed at making patients informed how to get rid of mind control strategies, how do not mingle with annoying thoughts, and how to tolerate more unpleasant emotions, such as anxiety. In fact, the use of detachment and acceptance techniques reduced the severity of these situations for the patients, and although this treatment did not directly improve the condition of the cardiac patients, according to Forbes, reduced the anxiety of stressful situations by using detachment and acceptance techniques, led to increased resilience [54]. In other words, ACT, in the first place, allows patients to change relationships with their inner experiences, reduce experiential avoidance, increase flexibility, and take more action in valuable paths. The re- sults of Barros' research showed that ACT led to greater adherence to values and improved quality of life and satisfaction. Also, Goodwin et al. showed that behavioral therapy based on ACT effectively and significantly improved the quality of life of chronic cardiovascular patients and their adherence to positive life changes [55]. In the ACT, behavioral commitment exercises along with detachment and acceptance techniques, as well as detailed discussions about one's values and goals and the need to clarify values, led to the regulation of emotions and increased resilience and better perception of the disease. By substituting themselves as the context, clients were able to easily experience unpleasant inner events in the present and were able to detach themselves from unpleasant reactions, memories, and thoughts [25].

Pursuing valuable goals in life and commitment to achieve these goals can lead to improved performance and reduced psychological distress in the clients [56]. ACT puts emphasis on accepting as many unpleasant feelings as possible, concentrating on the present moment, and engaging in activities that are in line with personal values related to behavioral goals [14]. Also, cardiac patients feel death more than ever before. This treatment helps the patient to deal with stressful situations by increasing mindfulness, cognitive distancing (observation of thoughts), active involvement in the outside world, and striving to achieve a meaningful and genuine life to increase psychological resilience [25].

The results also showed that guided imagery was effective in increasing the resilience level of cardiac patients, which is consistent with the results of Hollier et al. [52], Menzies et al. [53], Penzien et al. [54], and Abdoli et al. [55].

In explaining the effectiveness of guided imagery therapy, it can be said that mental image is the main theme of human personality and behavior. A change in the mental image can change a person's personality and behavior. All our actions, feelings, behaviors, and even abilities are shaped by this mental image [57]. Dibbets and Arentz believe that techniques, such as mental rotation, mental screening, muscle relaxation, and cognitive retrieval are skills that not only target a particular subject, image, and thought but also by replacing positive mental thoughts and images with negative thoughts and images, they play an important role in increasing psychological well-being, resilience, and quality of life, as well as reducing internal conflict. Some theories suggest that positive mental imagery weakens the hormonal and psychoneuroimmunological pathways that affect stress responses. According to the gate control theory, only one impulse can travel from the spinal cord to the brain at the same time, and if this pathway is occupied by the imagination, the sensation of pain cannot go to the brain; therefore, 
the pain is reduced [58]. In this regard, Motahhari et al. consider mental imaging as a factor in improving the activity of patients with multiple sclerosis [59]. Guided mental imagery is effective in diverting the patient's mind from annoying stimuli, creating relaxation, affecting the patient's mood, and increasing resilience.

The greater effectiveness of ACT than guided imagery is explained by the fact that in guided imagery, more emphasis is placed on changing mental images in the direction of recovery, while in the ACT the emphasis is on disease acceptance, commitment to disease acceptance, and reassessment of goals. In this treatment, the main issue is the active and conscious acceptance of unpleasant life experiences. The patient can learn how to eagerly deal with his/ her emotions, memories, physical feelings, and thoughts, how to avoid physical and psychological problems, and have a more active role in his/her life. Given that the problems and limitations caused by the disease cause patients to ignore their values; therefore, this method informs them about their usual solutions, sets goals for them, and motivates them to face more obstacles. In general, the goal of this type of treatment is to perform practical exercises and increase psychological flexibility, acceptance, cognitive defusion, and mindfulness. By doing these exercises, the patients get rid of the unpleasant experiences of the past, and by changing the reassessment of the current situation, their adaptation increases and their resilience improves.

Considering the effectiveness of ACT-based group therapy in improving cardiac patients, to generalize the results, it is recommended that this treatment be used as selective and complementary psychotherapy along with providing medical and pharmacological treatment to reduce psychological symptoms of cardiac patients and improve their living standards. It is also recommended that this method be used for the treatment of psychological disorders of other chronic patients and clinical disorders in different age and cultural groups, and the results be compared with drug therapy, either individually or in groups. Third, in the clinical context of cardiac patients, resilience components and coping strategies should be taught so that the affected patients can overcome the problems and pain caused by this disease. Fourth, in the implementation of treatment protocols, especially ACT, local allegories and metaphors should be used in accordance with the culture of the region.

\section{Conclusion}

Since the cardiac disease is one of the most common diseases in today's society and has psychological backgrounds; thus, according to the results of this study, psychological interventions, such as the ACT and guided imagery can significantly increase the resilience of cardiac patients and improve their physical and mental condition. This type of treatment is an effective non-pharmacological method in the psychological management of this disease and it is necessary to be considered as an effective treatment along with drug therapy. By recognizing their feelings and emotions, clients can continue their valuable cognitive and behavioral activities away from the exaggerated evaluation of their inner experiences. At the same time, they can reduce their stress levels, leading to an increase in their quality of life.

\section{Ethical Considerations}

\section{Compliance with ethical guidelines}

This paper approved by Ahvaz Branch, Islamic Azad University Ethics Committee Code: IR.IAU.AHVAZ. REC.1398.012). The study also has been registered in the Clinical Trial Registration Center of Iran on 06/26/2009 (Code: Number IRCT20190727044345N1). Also, this research has obtained legal permissions from the director of Imam Reza Hospital in Mashhad. Training sessions were held to inform participants of the way of conducting the research and to keep personal and related information confidential, to allow them to leave research whenever they wished. A written consent obtain from participants. They were given questionnaires before treatment intervention, and participants' rights were explained for them.

\section{Funding}

This article is part of a $\mathrm{PhD}$. dissertation of the first author entitled "Comparison of the Effectiveness of ACT and Guided Imagery on Disease Perception, Resilience, and Emotional Regulation (Positive and Negative) of Cardiac Patients Referred to the Cardiac Rehabilitation Department" approved by the Persian Gulf International, Khorramshahr-Khalije Fars Branch, Islamic Azad University, Khorramshahr, Iran.

\section{Authors' contributions}

Final compilation: All authors; Research design, data collection, writing the initial version, final review: Abbas Ali Shahabi; Main idea, writing the original edition, final review: Parvin Ehteshamzadeh; Interpreting data, writing the original version, final review: Parviz Asgari; Interpreting data, writing the original edition, final review: Behnam Makvandi.

\section{Conflicts of interest}

The authors declared no conflict of interest. 


\section{Acknowledgements}

We would like to thank all the patients and the staff of Imam Reza Hospital in Mashhad City (cardiac rehabilitation department) for their cooperation in this research. 


\title{
مقايسه اثربخشى درمان مبتنى بر يذيرش و تعهلد و تصوير سازى ذهنى هدايتشده بر تابآورى

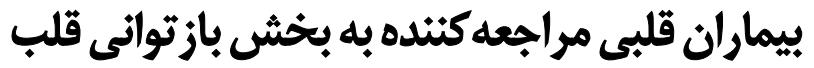

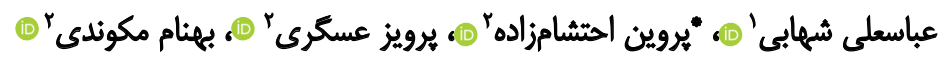 \\ ا. ا.كروه روانشناسى سلامت، واحد بينالمللى خرمشهر - خليج فارس، دانشكاه آزاداسلامى، خرمشهر، ايران.

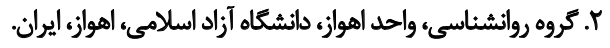

\begin{abstract}
حكיe

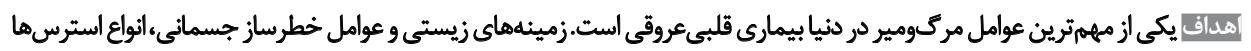

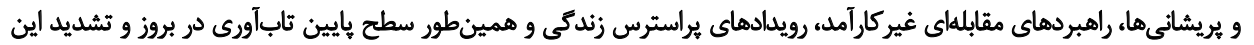

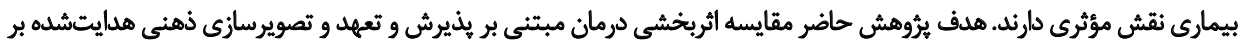

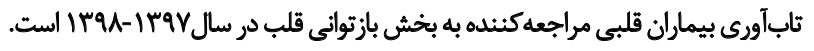

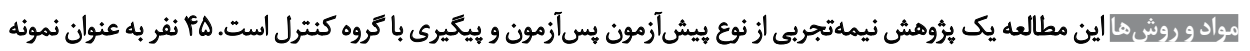

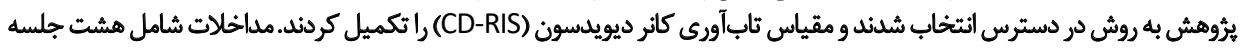

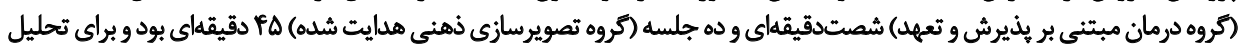

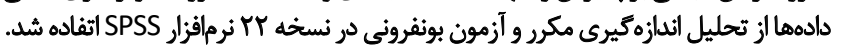

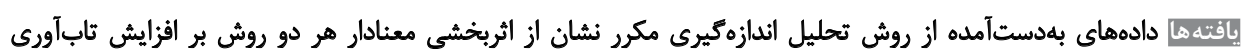

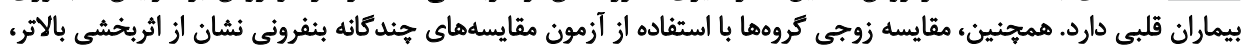

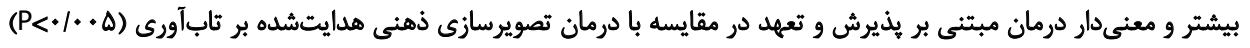

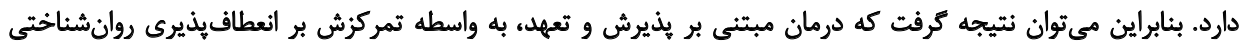

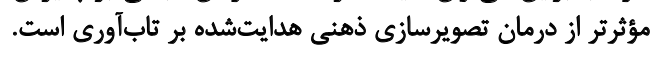

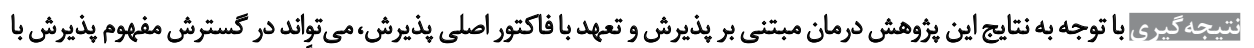

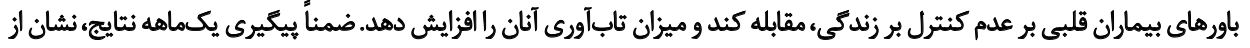
يايدارى و تقويت آن داشته است.
\end{abstract}

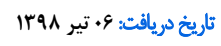

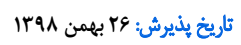

تاريخ انتشار: 11 تير 149

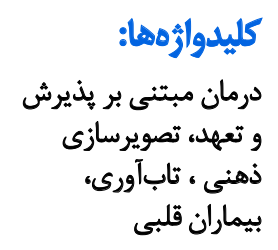

كليدوارهها:

درمان مبتنى بر يذيرش

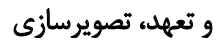

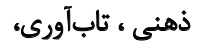
بيماران قلبى البي

بيمارىهاى قلب و عروق از شايعترين بيمارىها در كشورهاى

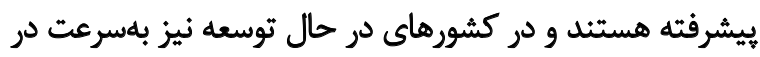

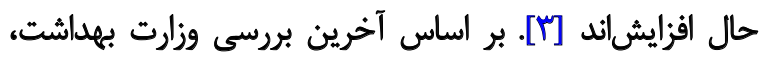

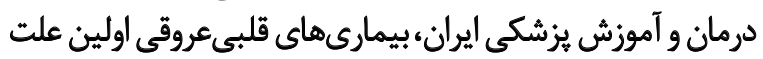

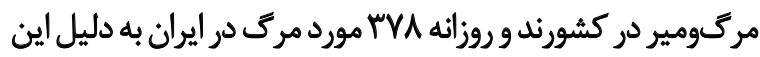

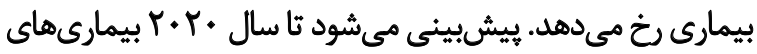

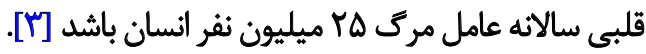

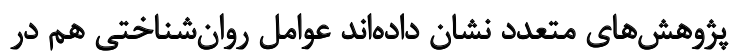

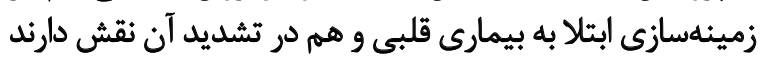

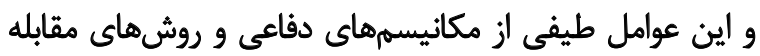

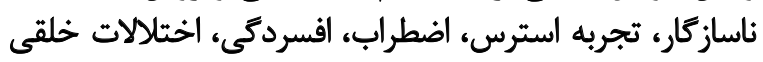

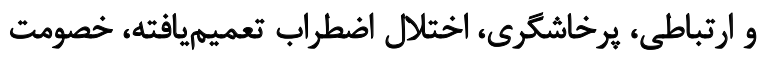

مeدمd

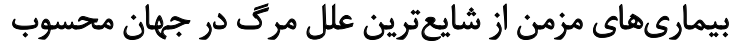

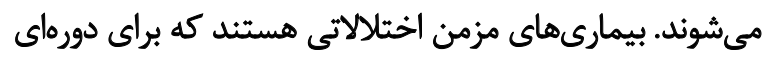

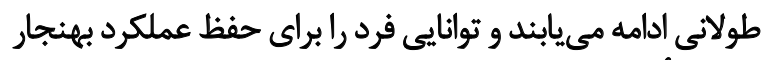

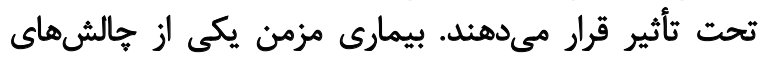

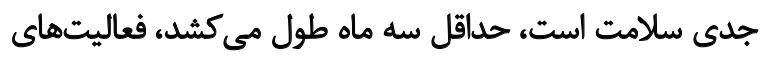

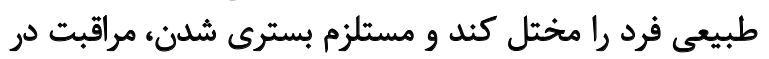

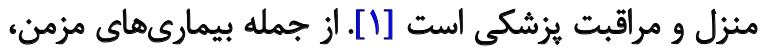

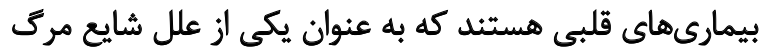

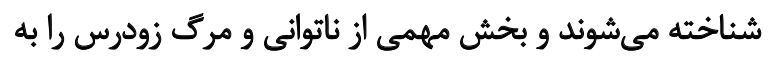
خود اختصاص مى دهند [Y]

$$
\text { ㄷ... }
$$

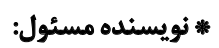

دكتر يروين احتشامزاده

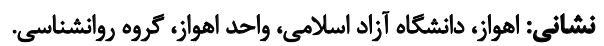
تلفن: ehtesham@iauahvaz.ac.ir يست الكترونيكي، 
است تا بتواند به روشهاى متفاوتى با تجاربش ارتباط برقرار كند

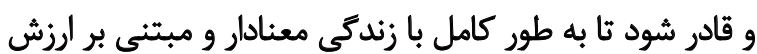

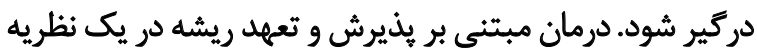

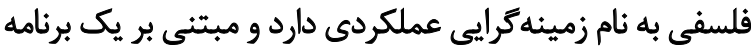

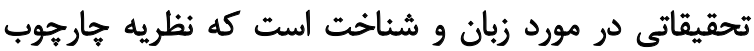

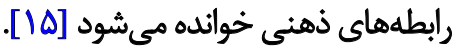

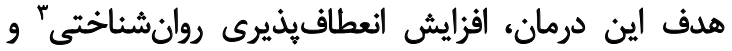

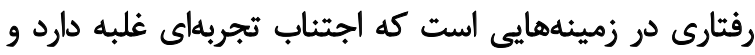

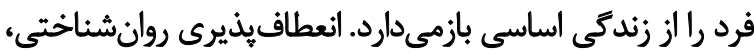

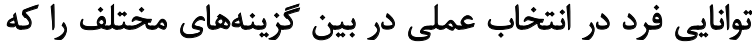

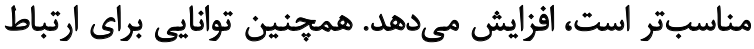

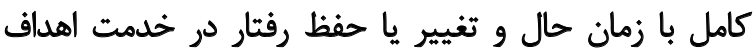

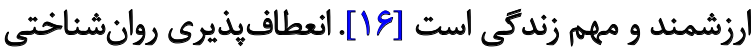

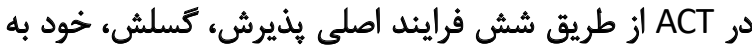

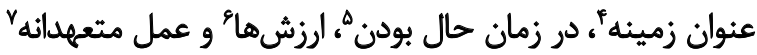

$$
\text { انجام مي كيرد [IV] }
$$

يروهش هاى اخير كه بر اساس درمان مبتنى بر بذيرش و وتعهد

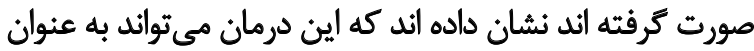

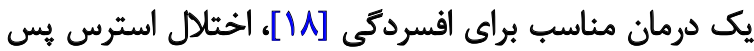

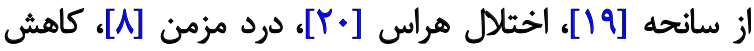

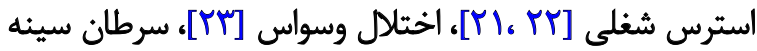

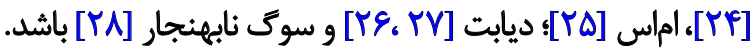

هافمن و همكاران نيز دريافتند رويكردهاى درمانى جندانيانه

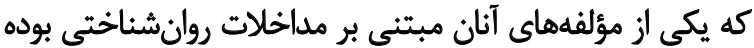

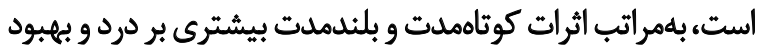

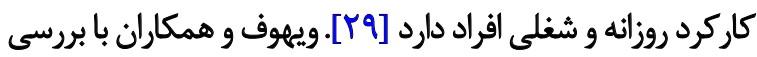

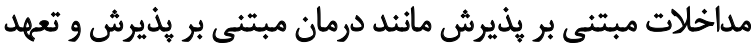

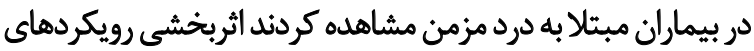

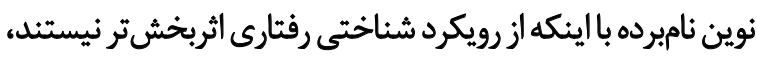

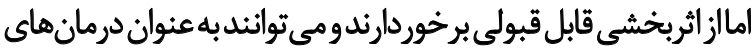

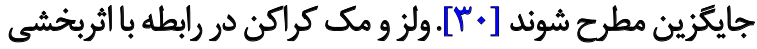

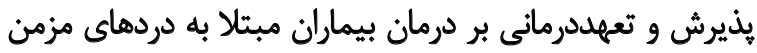

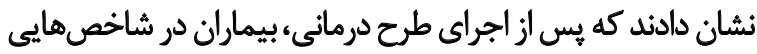

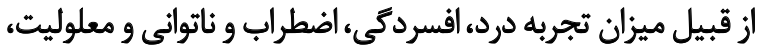

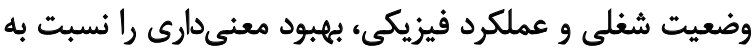

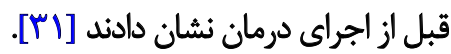

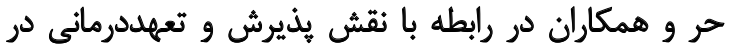

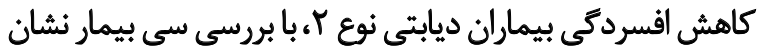

3. Psychological flexibility

4. Self as context

5. Being present

6. Valuing

7. Committed action
بينفردى، افكار و رفتارهاى وسواسى و ترسهاى مرضى تأ

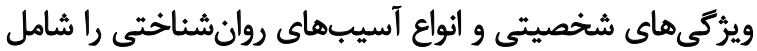

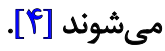

نارسايىهاى قلبى باعث ايجاد علاثم متعددى مى بشود و

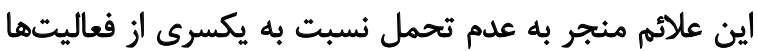

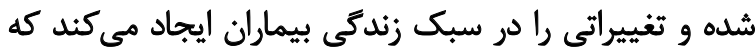

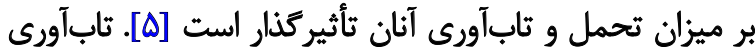

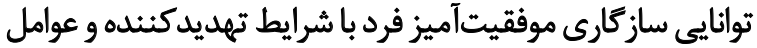

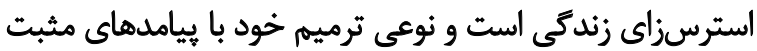

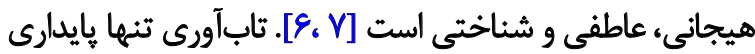

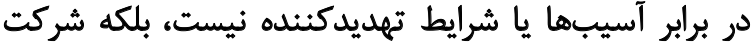

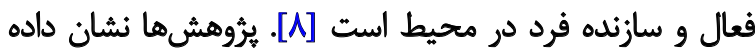

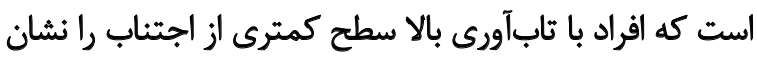

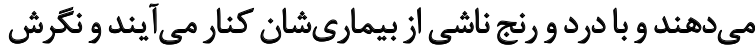

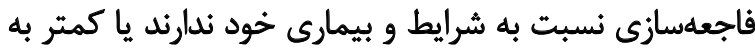

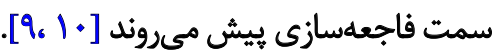

تابآورى' طى ده سال كذشته توجه بسيارى از محققان

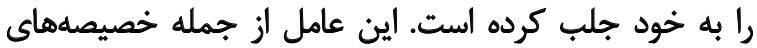

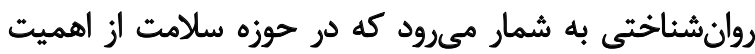

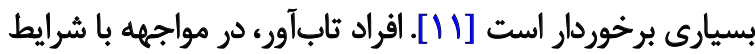

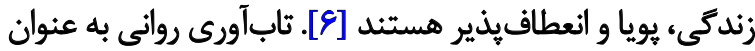

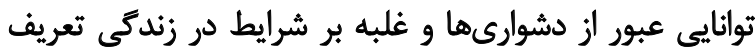

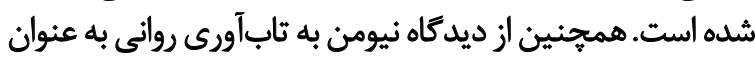
توانايي تطابق با دشوارىها اشاره شده است. تابآورى نارئ نهفيط

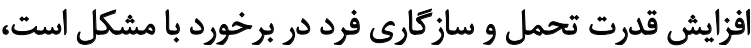

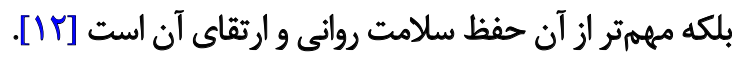
ورنر تابآورى افراد را عامل توانمندى آنان در راستاى تغيير

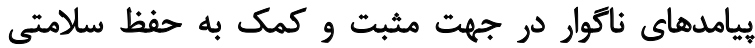

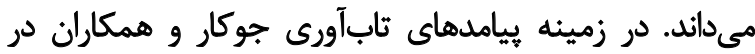

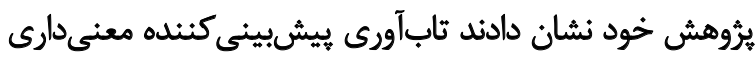

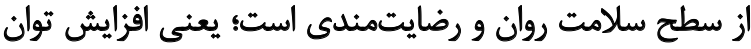

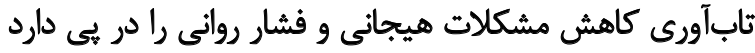

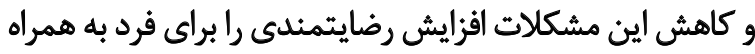

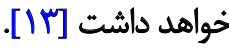

يكى از جديدترين درمانهاى هوج سوم روانشناختى كه

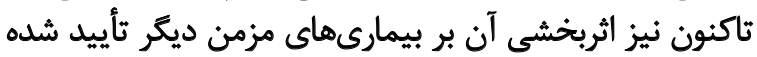

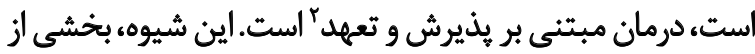

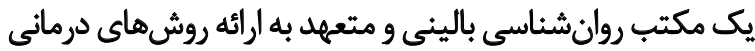

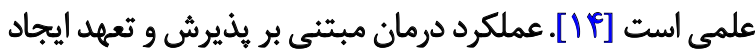

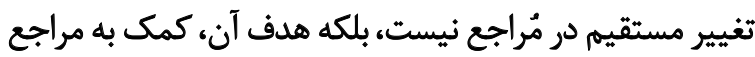

1. Resilience

2. Acceptance and Commitment Therapy 
بهبود اين بيماران و با توجه به گسترش درمانهاى روانشناختى

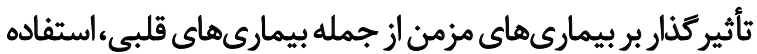

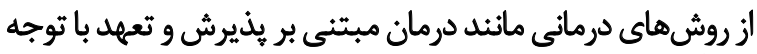

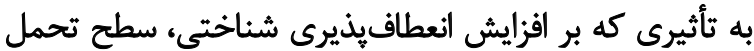

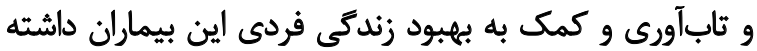

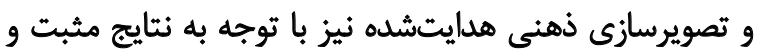

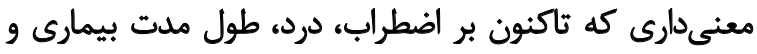

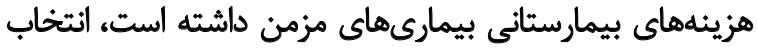

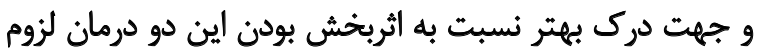
مقايسه اين دو درمان احساس شد.

با توجه به مرور ييشينه يزوهشى، هيتج مطالعهاي بل بررسى تأثير

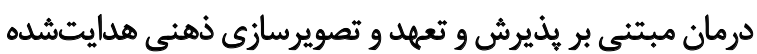

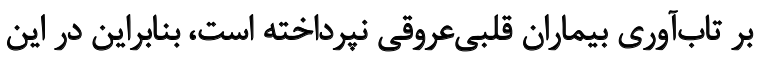

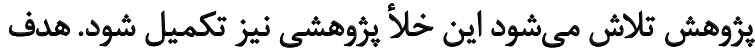

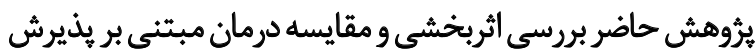

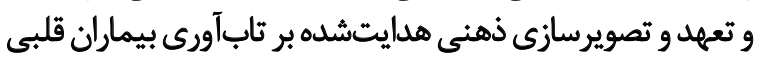
مراجعه كننده به بخش بازتوانى قلب است.

\section{مواد وروش}

اين كارآزمايى بالينى بر روى بيمار ان قلبى عروقيى مراجعه كنينده

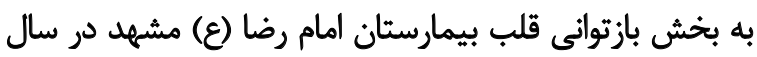

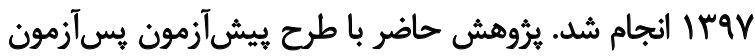

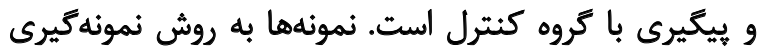

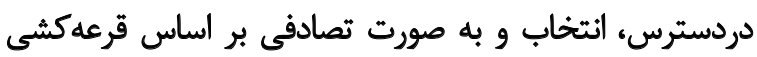

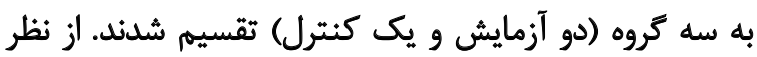

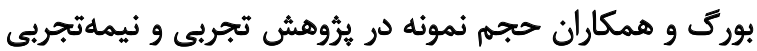

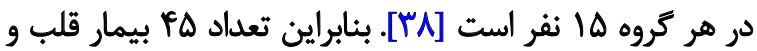

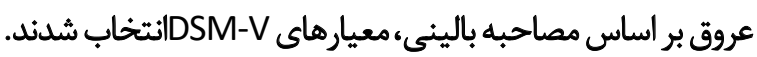

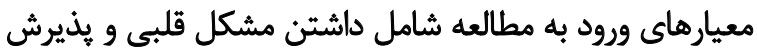

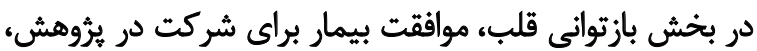

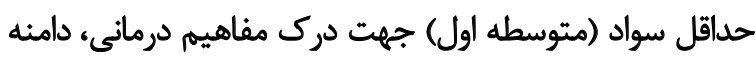

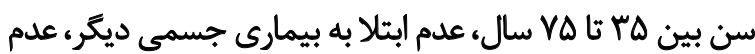

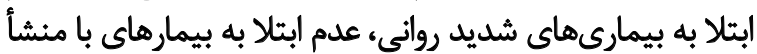

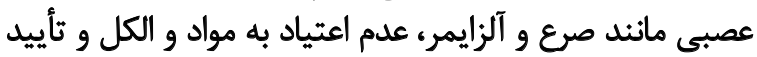

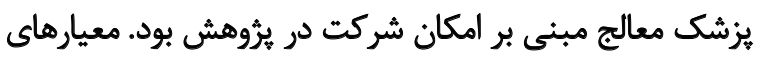

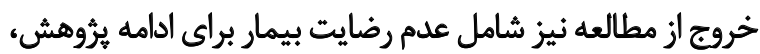

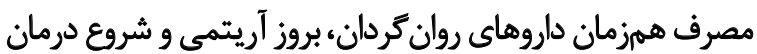
آن و CPR بيمار در حين مداخله بودمان رون

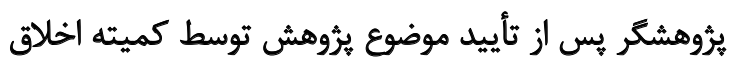

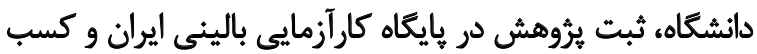

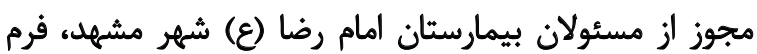

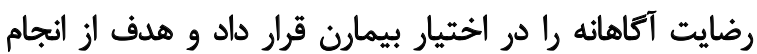

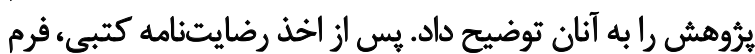

دادند كه اين روش درمانى در كاهش افسردگى بيماران ديابتى

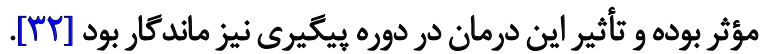

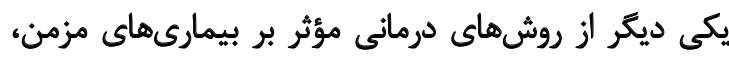

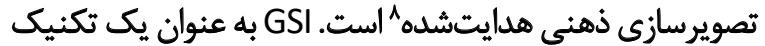

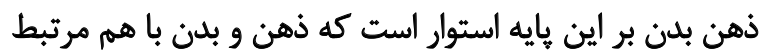

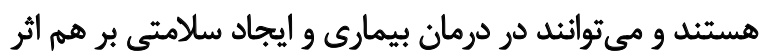

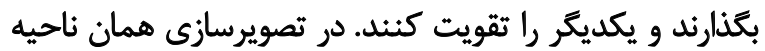

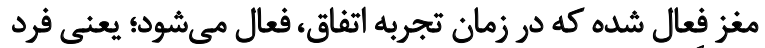

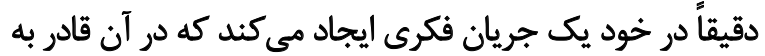

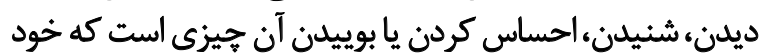

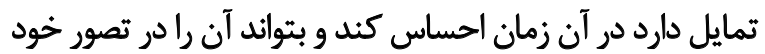

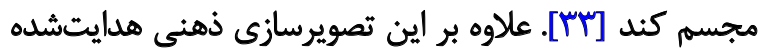

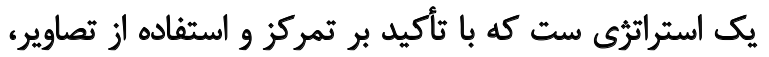

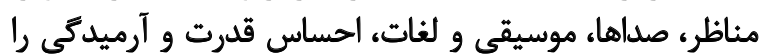

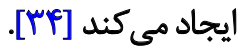

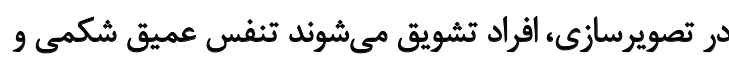

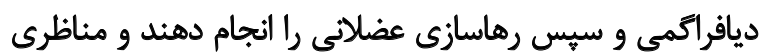

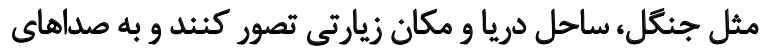

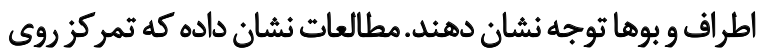

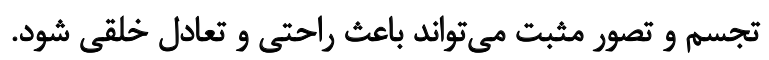

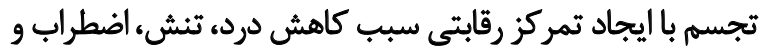

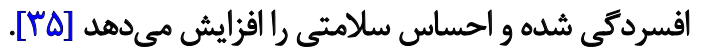

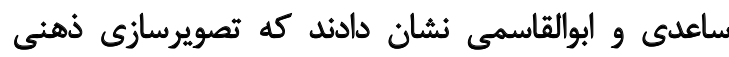

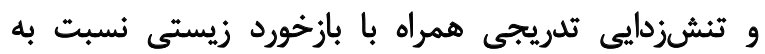

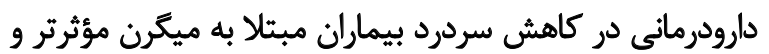

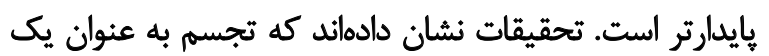

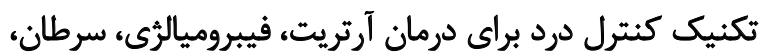

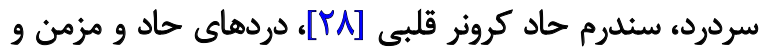

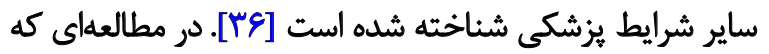

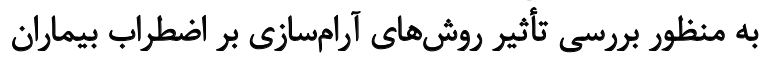

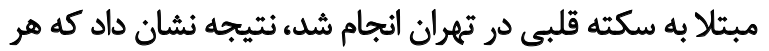

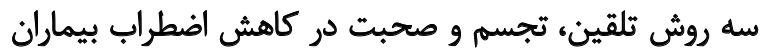

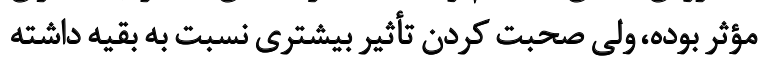

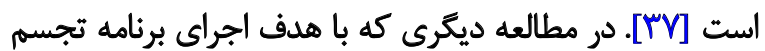

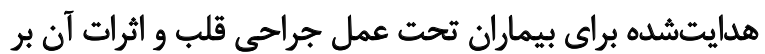

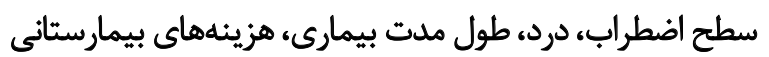

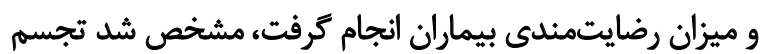

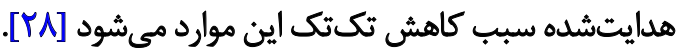

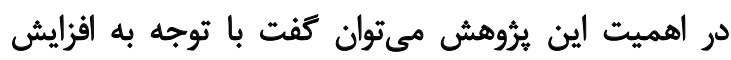

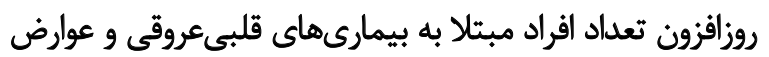

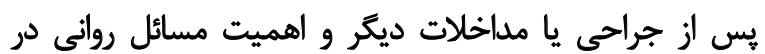

8. Guided Subjective Imaginery 
جدول ا. خلاصه محتواي جلسات آموزشى

\begin{tabular}{|c|c|}
\hline محتواى جلسات & جلسه \\
\hline آشنايعى آزمودنى ها با هم و صحبت كردن راجع به برنامه و اهداف يُروهش و توجيه آزمودنىها & اول \\
\hline به افراد كمك شد، تا باورهاى غلط و افكار غيرمنطقى خود را بشناسند. & دوم \\
\hline 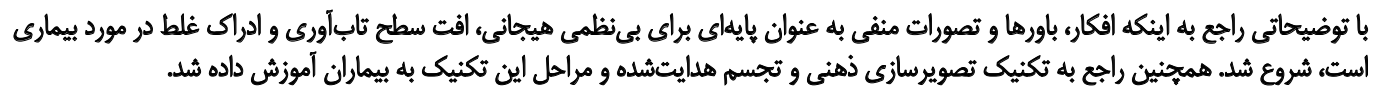 & سوم \\
\hline راههاى مقابله با افكار و تصورات منفى آموزش داده شد. & جهارم \\
\hline 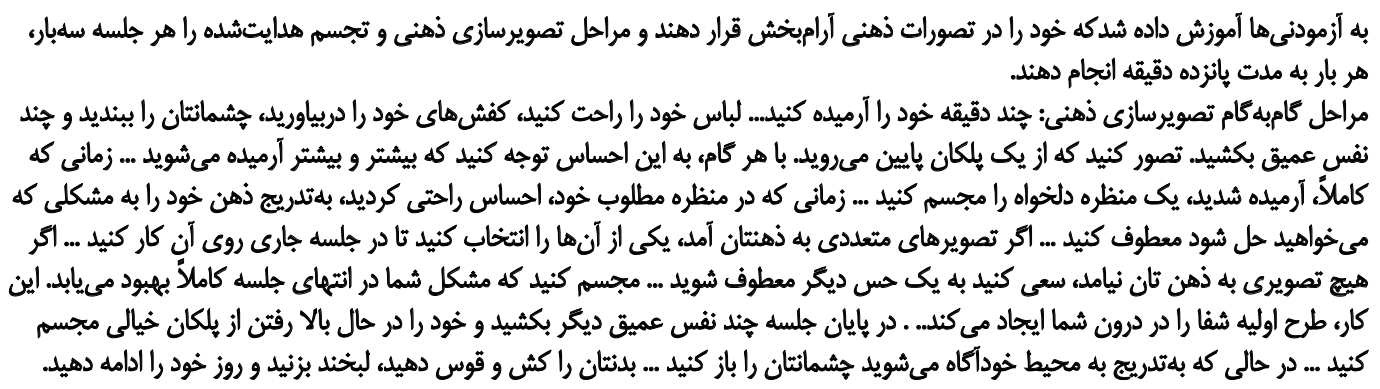 & يُجنم تأدهم \\
\hline
\end{tabular}

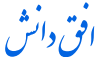

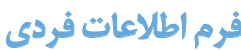

فرم اطلاعات فردى كه براى جمعآورى منظمه اطلاعات آزمودنى ها

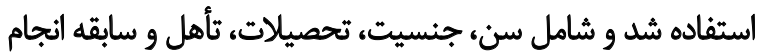

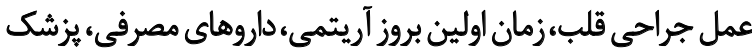
معالج، درمانهاى دريافتشده و طول مدت بيمارى بوده.

\section{"يرسشثامه تابآورى كائر ديويدسون"}

يرسشنامه تابآورى كانر ديويدسون يك ابزَار هاكويهاي است

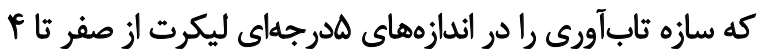

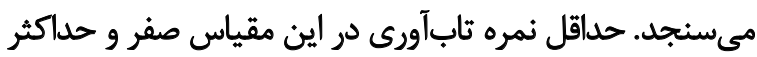

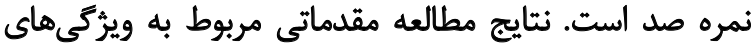

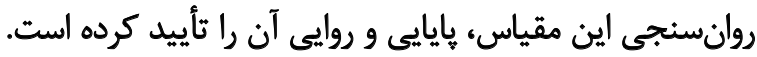

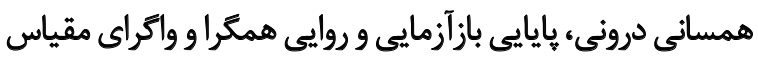

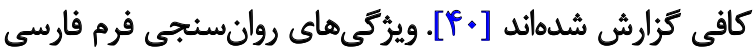

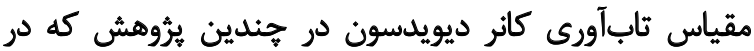

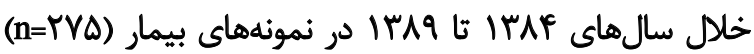

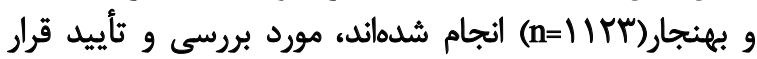

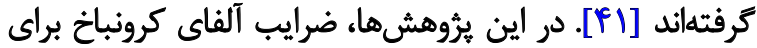

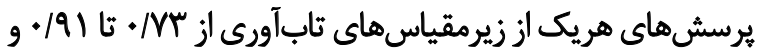

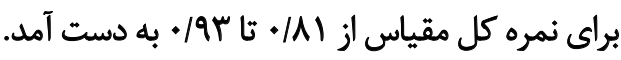

دادهها با كمك نسخه بَ نرمافزار SPSS شامل آزمونهاى ييشفرض لوين (اطمينان از همكنى واريانسها) و كولموكروف آزون
اطلاعات جمعيتشناختى و يرسش نامه تاب آورى كائر ديويدسون

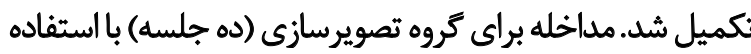

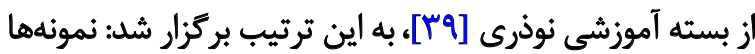

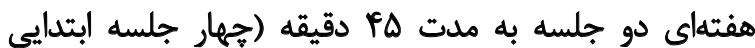

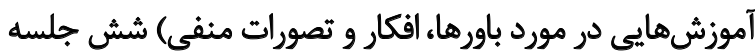

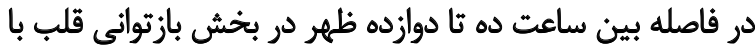

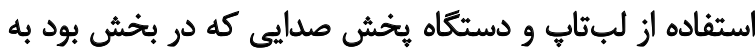

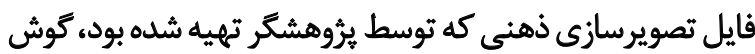

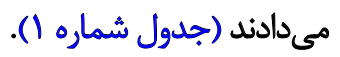
براى كنترل عوامل مداخله كر و دقت در استفاده از فايل صوتى،

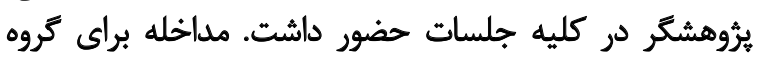

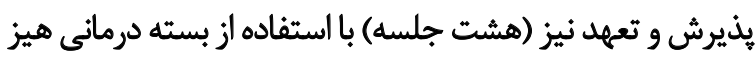

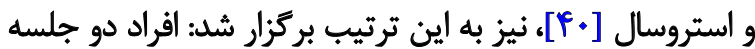

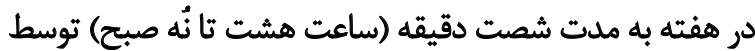

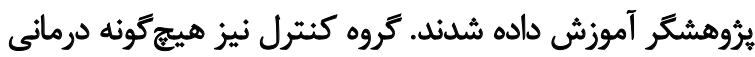

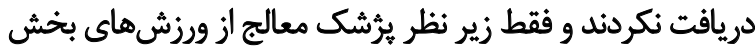

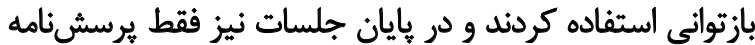

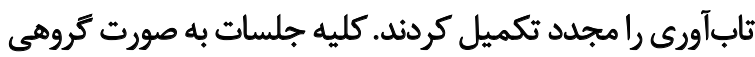

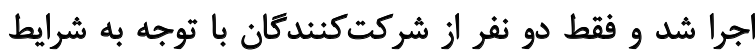

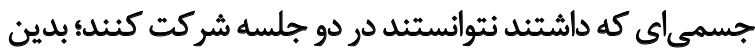

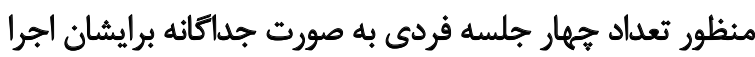

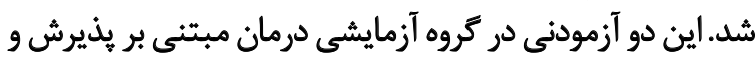

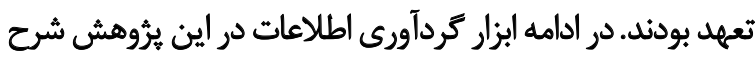
(جاده مىشوند (جدول شماره r). 
جدول r. خلاصه محتواى جلسات آموزشى ACT

آشنايع اوليه با مراجع و برقرارى رابطه مناسب با هلف ير كردن صحيح يرسش ئامهنا و ايجاد اعتماد؛ اجراى يرسش نامه جمعيتشناختى، رضايتنامه و

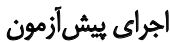

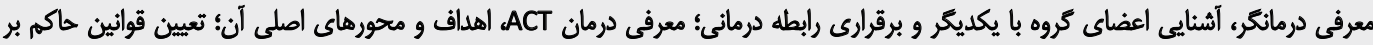

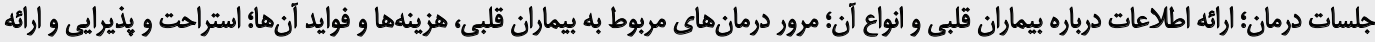
تكليف خانكى

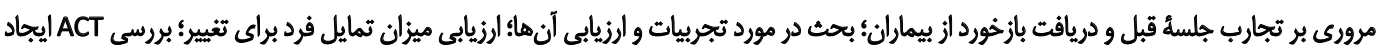

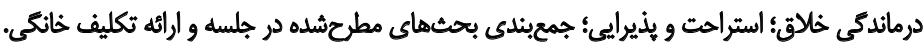

جلسه اول

جلسه دوم

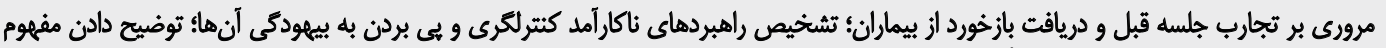

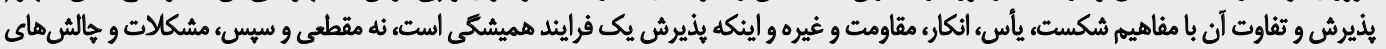

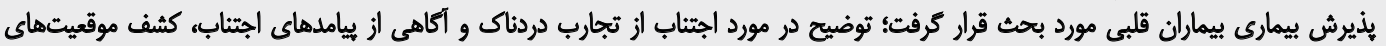

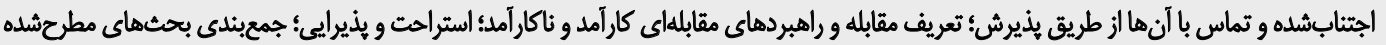
در جلسه و بررسى تمرين جلسه بعدئ ارائه تكليف خانكي.

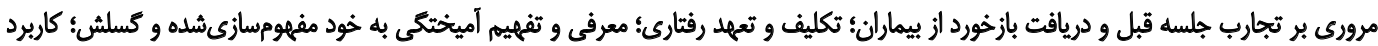

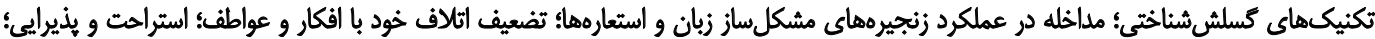

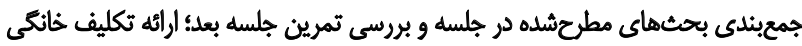

جلسه جهارت

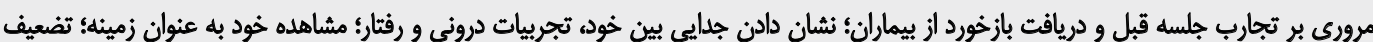

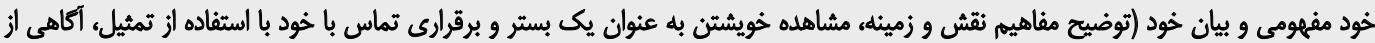

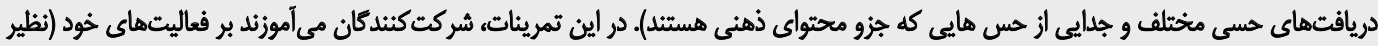

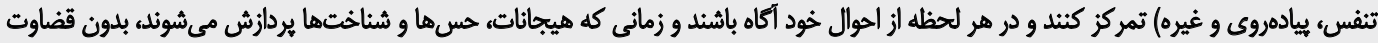

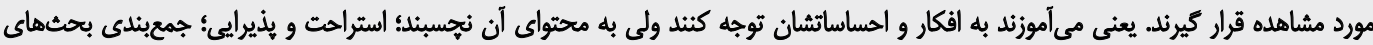

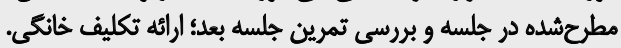

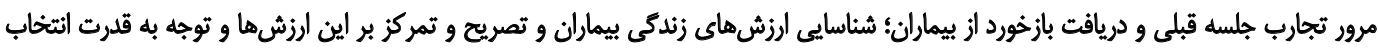

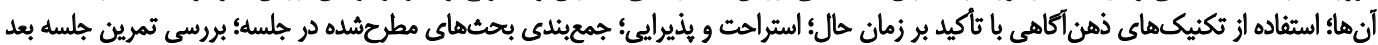
و ارائه تكليف خانكى.

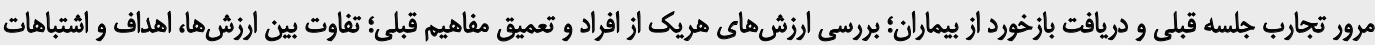

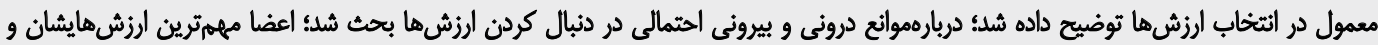

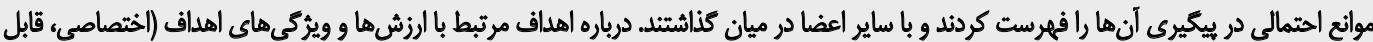

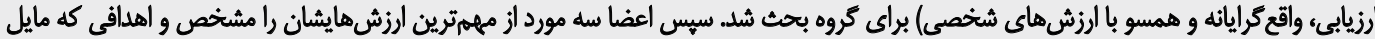

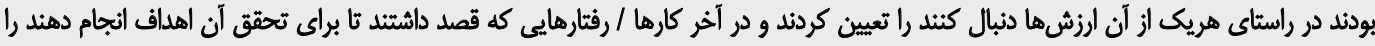

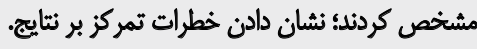

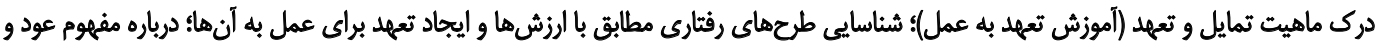

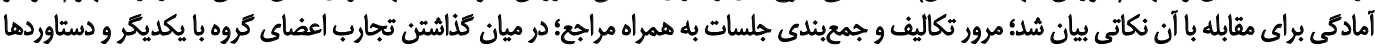

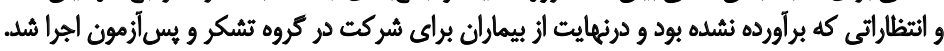

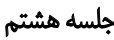

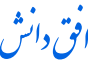

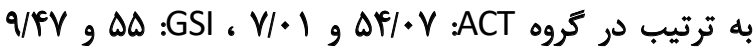
و كنترل:

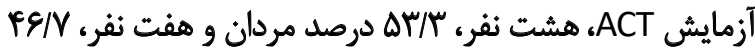

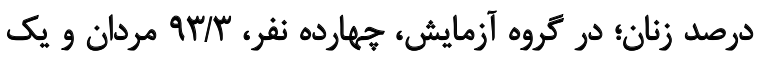

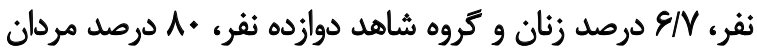

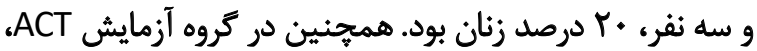

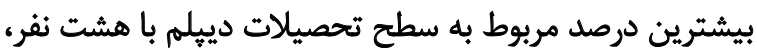

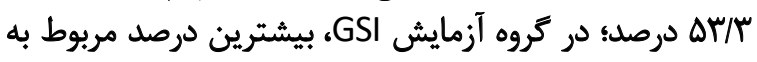

اسميرنف (براى اطمينان از نرمال بودن دادهها) و تحليل

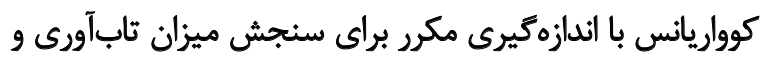

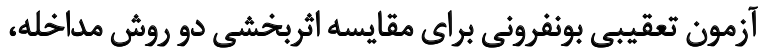
تجزيه و تحليل شدند.

Ladị

در بُثوهش حاضر ميانكين و انحراف معيار سنى آزمودنىها 
جدول ץ. ميانكين و انحراف استاندارد سلبار اندازهيرى نمره تابآورى در كروههاي آزمايش(GSI ACT) و كنترل

\begin{tabular}{|c|c|c|c|c|c|}
\hline \multicolumn{3}{|c|}{ ميانكين Е انحراق معيار } & \multirow{2}{*}{ تعداد } & \multirow{2}{*}{ ه } & \multirow{2}{*}{ مثغير } \\
\hline بييكيرى & ئس أزهون & بيش آزمون & & & \\
\hline$P T / P Y \pm \Delta / F \Delta$ & $E V / T V \pm \Delta / P \Delta$ & $r \mid / P V \pm r / q e$ & is & درمان مبتنى بر يذيرش و تعهد & \multirow{4}{*}{ ثاب آورى } \\
\hline$\Delta P / P= \pm T / \Delta C$ & $|V /| r \pm f|g|$ & $r \cdot / A V \pm Y / A V$ & 10 & تصويرسازى ذهني هدايتشده & \\
\hline 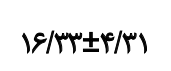 & $\Delta T / \cdot \pm \Psi / T H$ & $M T / Y \Psi \pm T / M$ & 10 & كتثرل & \\
\hline$\Psi V /+V \pm(\Delta / \Delta)$ & $q \mu / \Lambda \pm 1 \Delta / \Delta r$ & $r \varepsilon / \varepsilon q \pm(\mu / \mu)$ & $r \Delta$ & كل & \\
\hline
\end{tabular}

انوانٌ

جدول ه. نتايج تحليل كوواريانس بين آزمودنىها و درون آزمودنىها با اندازه كيرىهاى مكرر بر سهبار اندازهكيرى نمره تابآورى در كروههاى درمانى و كثترل

\begin{tabular}{|c|c|c|c|c|c|c|c|c|}
\hline \multicolumn{2}{|c|}{ مجذور اتا } & \multirow{2}{*}{ معنادارى } & \multirow{2}{*}{$F$} & \multirow{2}{*}{ ميائكين مجذورات } & \multirow{2}{*}{ دوجه آزادي } & \multirow{2}{*}{ هجموع مجذورات } & \multirow{2}{*}{ منبع اثر } & \multirow{2}{*}{ مقياس } \\
\hline ACT & GSI & & & & & & & \\
\hline \multirow[t]{3}{*}{$+/ M$} & . /AT & $+1+\infty$ & $1 E \& \Delta / A q$ & rvaril/ra & 1 & rvaVII/Tq & مرحله & \\
\hline & & .10 .1 & $19 \cdot 1 A T$ & 810489 & $r$ & rq//rmiq & كروه & تابآورى \\
\hline & & & & $\mathrm{rT} / \mathrm{TW}$ & Rr & $\mid r \Delta \Delta / A Y$ & خطا & \\
\hline
\end{tabular}

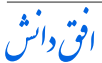

جدوله. نتايج آزمون تعقيبى بونقرونى براى مقايسه مقياس تابآورى در سه كروه

\begin{tabular}{|c|c|c|c|c|}
\hline سطح معنادارى & اخغنالف ميانئين & مراحل & دور مقايسه با كروه & كروه \\
\hline . IAV & $-1 / T E$ & & كثترل & \\
\hline y. & .18 & نييش آلزمهن & تصويرسازى ذهنى هدايتشده & درمان مبتنى بر بذيرش و تعهد \\
\hline ( & $-1 / N$ & & 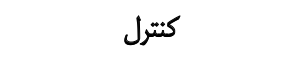 & تصويرسازى ذهنى هدايتشده \\
\hline $.1 \%+1$ & Mf/re* & & كنترل & \\
\hline $1++1$ & g/1"* & يسآزمون & تصويرسازى ذهنى هدايتشده & درمان مبتنى بر هذيرش و تعهد \\
\hline .101 & TNIT & & كثترل & تصويرسازى ذهنى هدايتشده \\
\hline $.1 . .1$ & $m e / 1 m^{m}$ & & كنترل & \\
\hline .10 .1 & $9 \cdot 9 V^{*}$ & ييكيرى & تصويرسازى ذهنى هدايتشده & درمان مبتنى بر هذيرش و تعهد \\
\hline $.10+1$ & $r \Delta / .8^{\circ}$ & & كنترل & تصويرسازى ذهنى هدايتشده \\
\hline
\end{tabular}

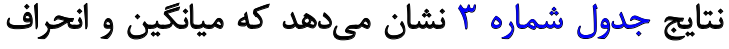

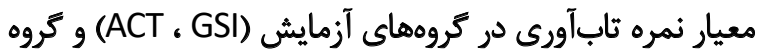
كنترل در سه مرحله، تفاوت محسوسى نروس را با يكديكر دارند. بررسى نتايج آزمون M باكس در مورد تساوى ماتريسهاى

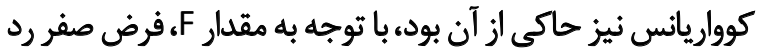

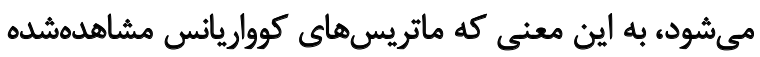

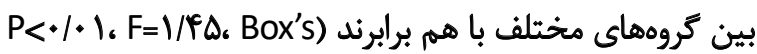

سطح تحصيلات دييلم با ينج نفر، س//T درصد و در كروه كنترل

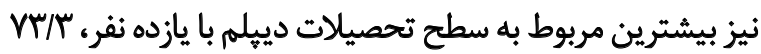

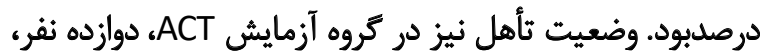

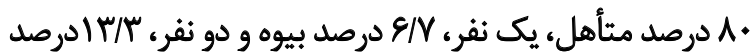

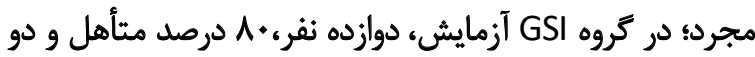

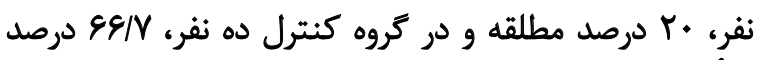

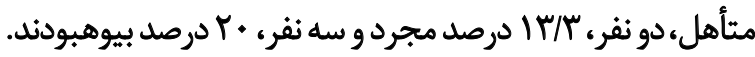


قرار داده نمى شد، به كُفته فوربس كاهش اضطراب موقعيتهاى تئهي

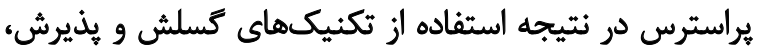

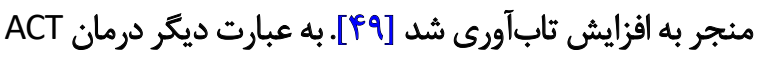

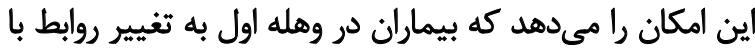

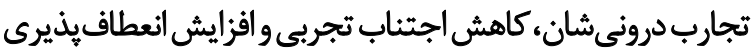

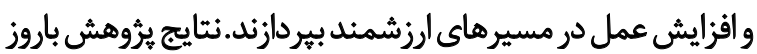

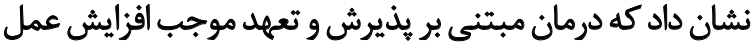

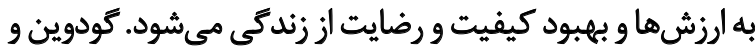

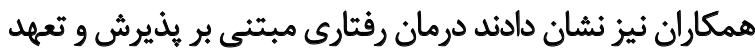

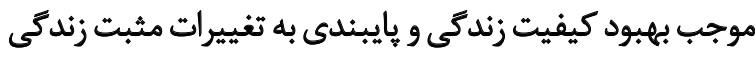

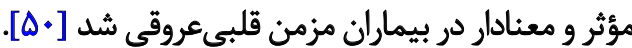
در درمان ACT تمرينهاى تعهد رفتارى به همراه تكنيكهاى

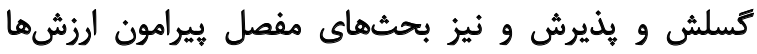

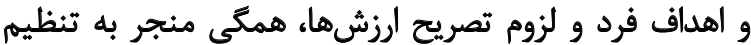

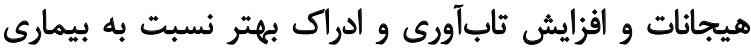

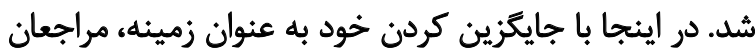

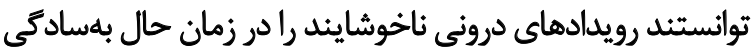

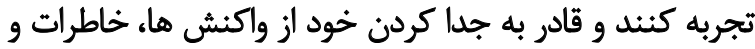

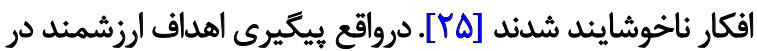

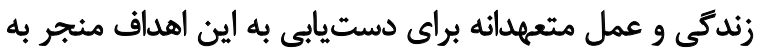

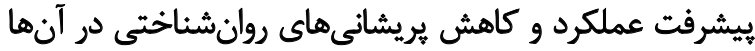

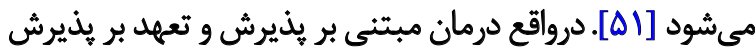

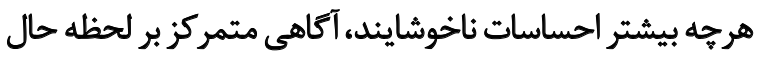

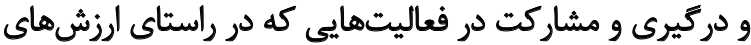

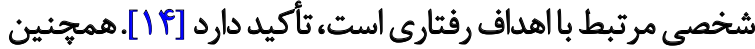

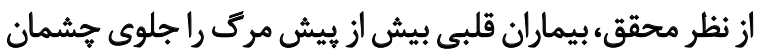

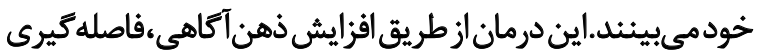

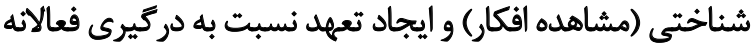

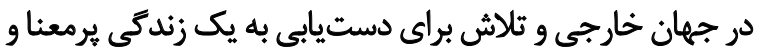

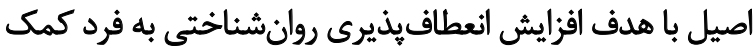

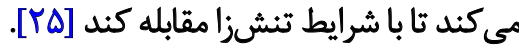

هميجنين نتايج بروهش نشان داد كه تصويرسازى ذهنى

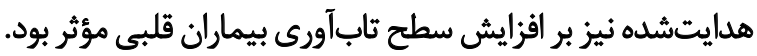

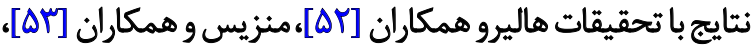

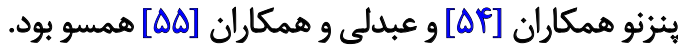
در تبيين اثربخشى درمان تصويرسازى ذهنى هدايتشده

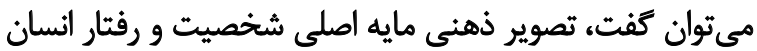

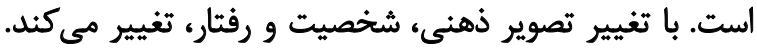

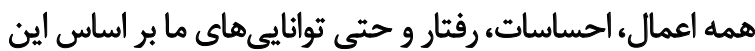

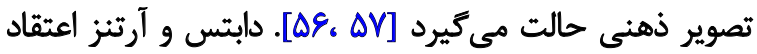

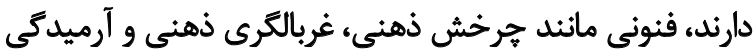

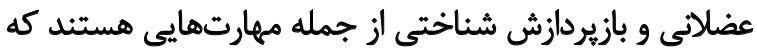

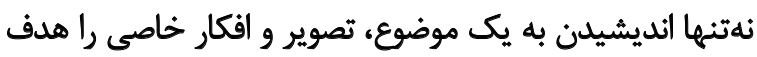

(M=19/F9). همجنين با بررسى آزمون لوين در مورد تساوى واريانس هاى خطا، فرض تساوى واريانس ها بارئ رعايت شد و وارين موريانس

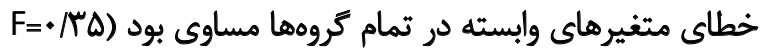

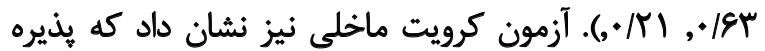

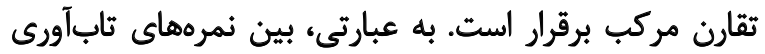

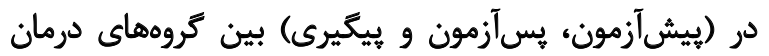

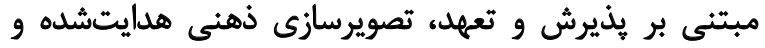

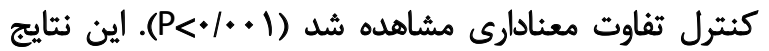

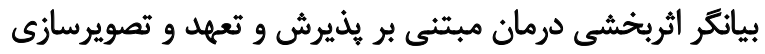

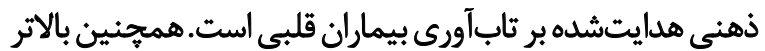

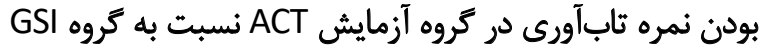

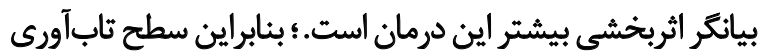

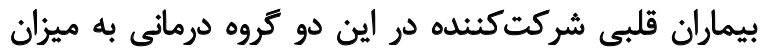
معنادارى افزايش يافته است (جدول شماره F). نتايج آزمون تعقيبى بونفرونى نشان ميى دهد كه نمرات متغير

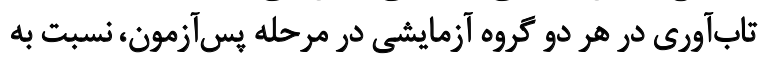

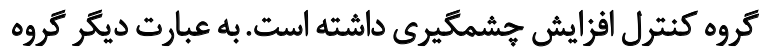

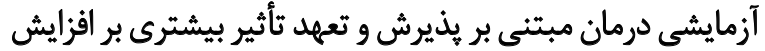

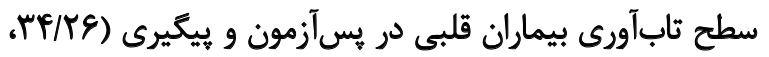

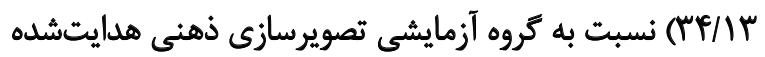

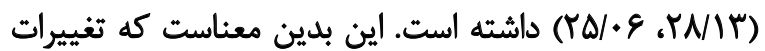

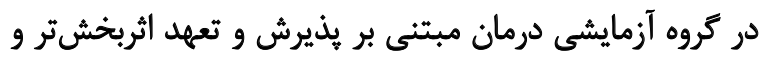

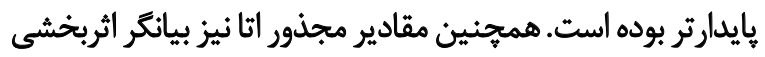

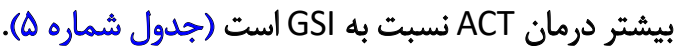

\section{ڤu}

برئوهش حاضر با هدف بررسى مقايسه اثربخشى درمان مبتنى تهري

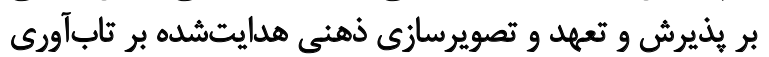

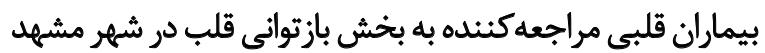

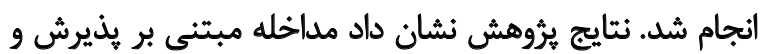
تعهد بر افزايش سطح تاب آورى بيماران قلبى مؤثر بود. نتايج با تحقيقات مولينا و همكاران [F[F]، قربانى و همكاران

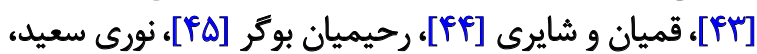

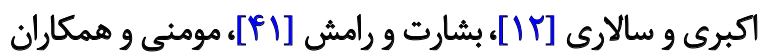

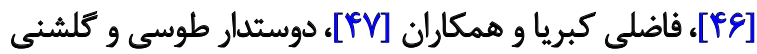

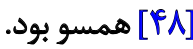

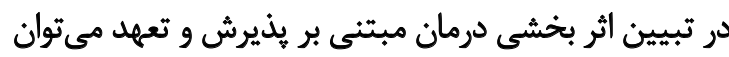

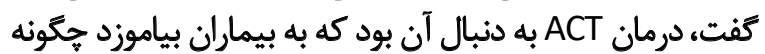

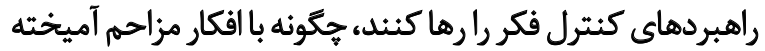

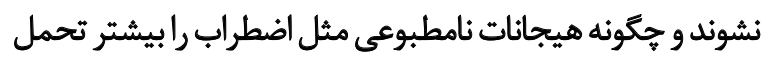

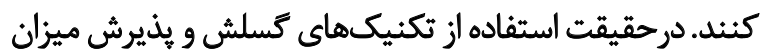

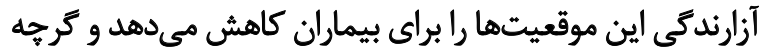

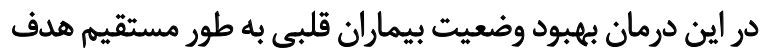


بكنند و يكى از روشهاى درمانى غيردارويى كارآمد در مديريت

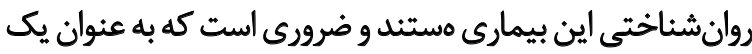

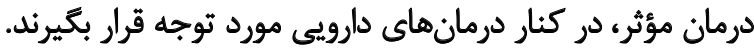

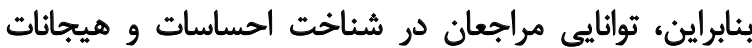

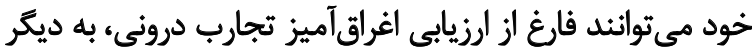

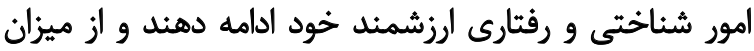
فشار روانى كاسته و در نتيجه اين كاهش فئشار إندار رواني كيفيت

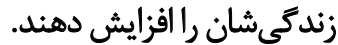

بيشنهاد مى شود به منظور توانيايى در تعميم بهتر نتايج، با توجه

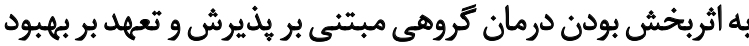

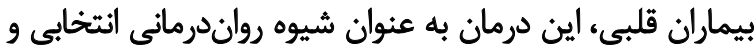

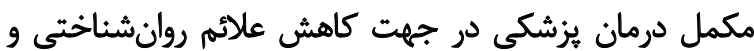

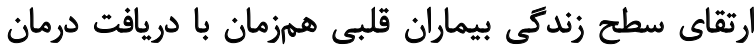

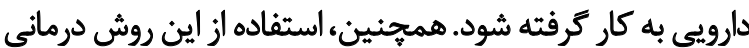

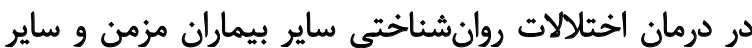

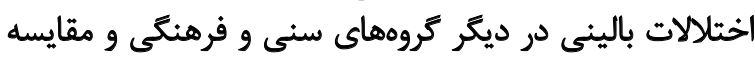

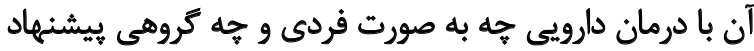

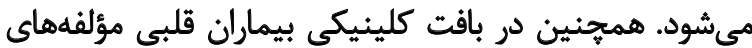

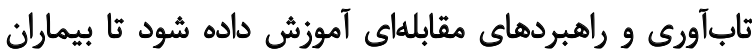

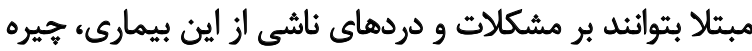

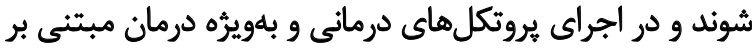

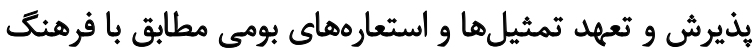

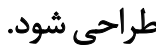

مالاحظات اخلاقى

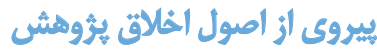

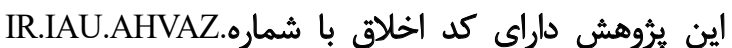

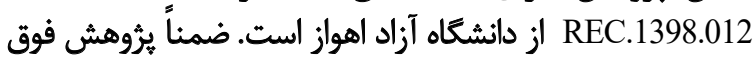

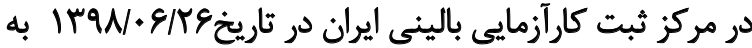

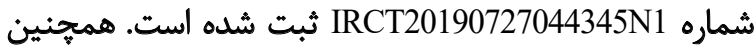
اين يثوهش مجوزهاى قانونى از رياست محترم بيمارستان امام

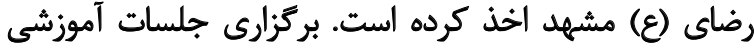

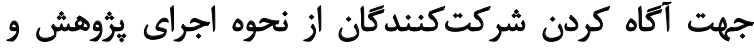

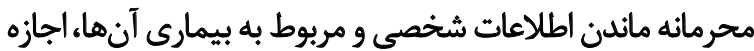

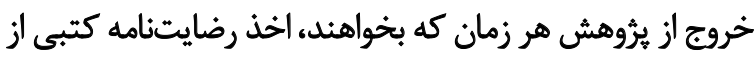

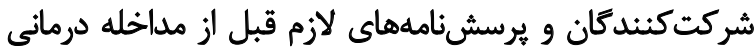

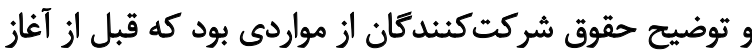

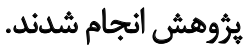

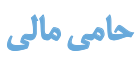

اين مقاله بخشى از زايانانامه دكترى تخصصى آقاى عباسعلى

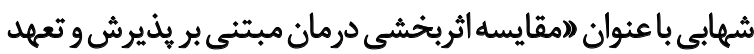

قرار مي دهند، بلكه با جايكزين كردن افكار و تصاوير ذهنى مثبت

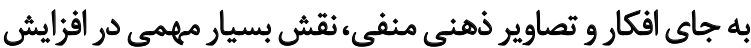

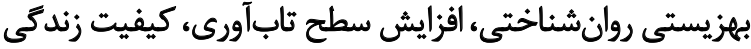

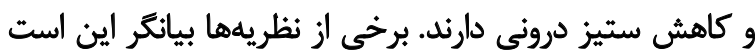

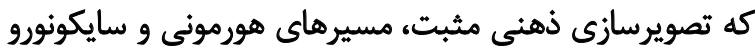

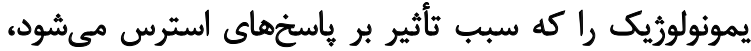

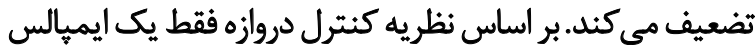

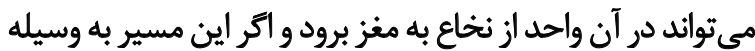

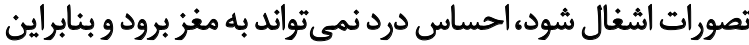

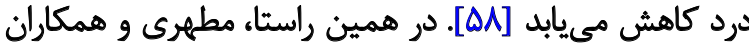

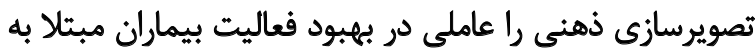

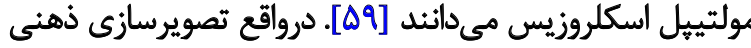

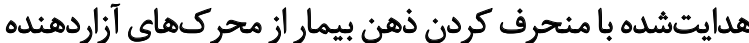

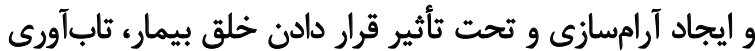

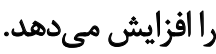

در توجيه اثربخشى بيشتر درمان مبتنى بر بذيرش و تعهيد

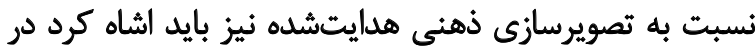

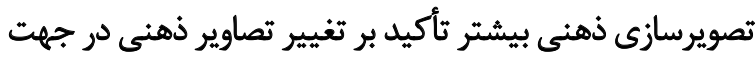

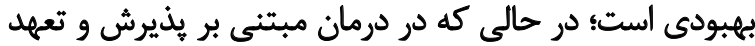

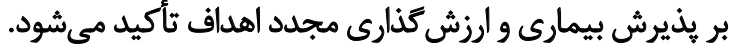
در اين درمان مسئله اصلى، بذيرش فعالانه و آكاهانه تجارب

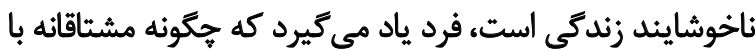

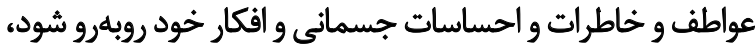

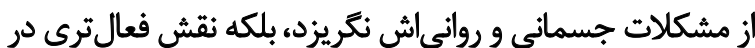

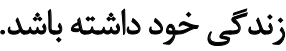

همجنين با توجه به اينكه اين درمان موجب آكاهي فرد نسبت

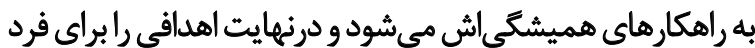

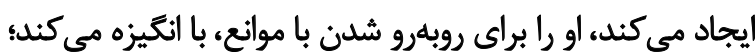

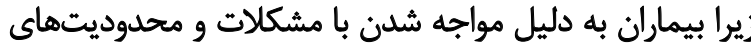

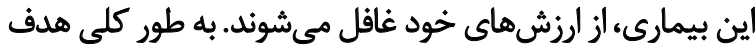

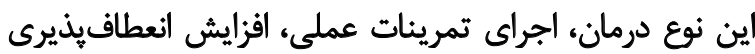

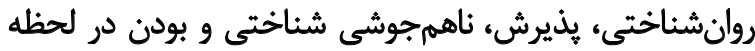

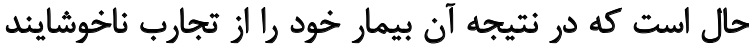

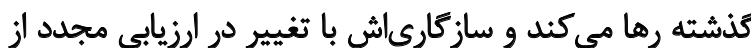

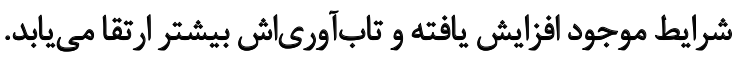

\section{تئيجهئيرى}

از آنجايى كه بيمارى قلبى يكى از بيمارىهاى شايع در

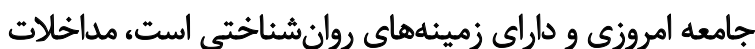

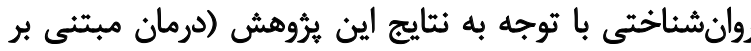

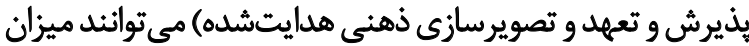

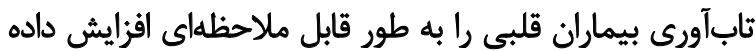

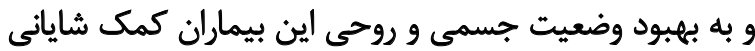


و تصويرسازى ذهنى هدايتشده بر ادراك بيمارى ، تابآورى و

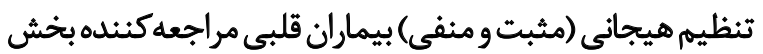

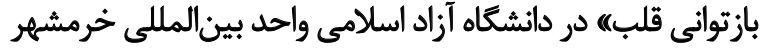

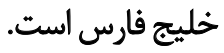

\section{مشاركت نويسندكّان}

نوشتن نسخه اوليه و بازبينى نهايى: همه نويسندگًان؛ تفسير إئري

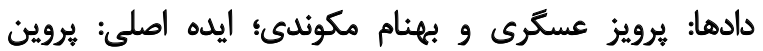

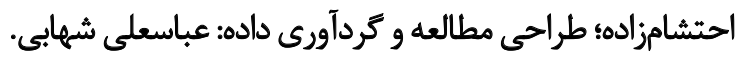

$$
\text { تقارض مناقع }
$$

بنابر اظهار نويسندكان، اين مقاله تعارض منافع ندارد.

$$
\text { تشكر وقدروانى }
$$

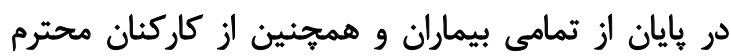
بيمارستان امام رضا (ع) مشهد (بخش بارئ بازتوانى قلب) برائ

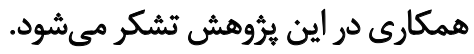




\section{References}

[1] Mokkink LB, Van Der Lee JH, Grootenhuis MA, Offringa M, Heymans HS. Defining chronic diseases and health conditions in childhood (0-18 years of age): National consensus in the Netherlands. European Journal of Pediatrics. 2008; 167(12):1441-7. [DOI:10.1007/s00431-008-0697-y] [PMID]

[2] Jiang G, Wang D, Li W, Pan Y, Zheng W, Zhang H, Sun YV. Coronary heart disease mortality in China: age, gender, and urban-rural gaps during epidemiological transition. Revista Panamericana de Salud Pública. 2012 31:317-24. [DOI:10.1590/S1020-49892012000400008] [PMID]

[3] Yousefi R, Asghari H, Toghyani E. [Comparison of early maladaptive schemas and cognitive emotion regulation in cardiac patients and normal individuals (Persian)]. Journal of Advances in Medical and Biomedical Research. 2016; 107:130-43. http://zums.ac.ir/journal/article1-3781-en.html

[4] Mohammad Pour S, Rahimian A, Mohammad Rezaei A. [The role of alexithymia and defensive style to predict the quality of life in patients with coronary heart disease (Persian)]. Journal of Zanjan University of Medical Sciences and Health. 2014; 23:48-60. http://zums.ac.ir/journal/ article-1-3087-fa.html

[5] Dunderdale K, Thompson DR, Miles JN, Beer SF, Furze G. Quality-of-life measurement in chronic heart failure: Do we take account of the patient perspective? European Journal of Heart Failure. 2011; 7(4): 572-82. [DOI:10.1016/j.ejheart.2004.06.006] [PMID]

[6] Karoly P, RuehIman LS. Psychological "Resilience" and its correlates in chronic cain: Findings from a National Community Sample. The Journal of Pain. 2006; 123:90-7. [DOI:10.1016/j.pain.2006.02.014] [PMID]

[7] Inzlicht M, Aronson J, Good C \& McKay L. A particular resiliency to threatening environments. Journal of Experimental Social Psychology. 2006; 42:323-36. [DOl:10.1016/j.jesp.2005.05.005]

[8] Brinkborg H, Michanek J, Hesser H, Berglund G. Acceptance and Commitment therapy for the treatment of stress among social workers: A randomized controlled trial. Behaviour Research and Therapy. 2011; 49(6):389-98 [DOI:10.1016/j.brat.2011.03.009] [PMID]

[9] Ong AD, Zautra A J, Reid MC. Psychological resilience predicts decreases in pain catastrophizing through positive emotions. Psychology and Aging. 2010; 25(3):516-23. [DOI:10.1037/a0019384] [PMID] [PMCID]

[10] Newton-John TR, Mason C, Hunter M. The role of resilience in adjustment and coping with chronic pain. Rehabilitation Psychology. 2014; 59(3):360-5. [DOI:10.1037/a0037023] [PMID]

[11] DoustdarTousi S A, Golshani S. [Effect of resilience in patients hospitalized with cardiovascular diseases (Persian)]. Journal of Mazandaran University of Medical Sciences. 2014; 24(116):102-9. https://www. researchgate.net/publication/289325389_Effect_of_resilience_in_patients_hospitalized_with_cardiovascular_diseases

[12] Noori S A, Akbari B, Salari A. [Comparing the psychological resiliency in patients with coronary artery disease and normal subjects (Persian)]. Journal of Guilan University of Medical Sciences. 2014; 23(91):47-52. file:///C:/Users/Negah-02/Downloads/67413977605\%20(1).pdf

[13] Ghanei Gheshlagh R, Sayehmiri K, Ebadi A, Dalvandi A, Dalvand S, Bagher Maddah S, et al. The Relationship Between Mental Health and Resilience: A Systematic Review and Meta-Analysis. Iranian Red Crescent Medical Journal. 2017; 19(6):e13537. [DOI:10.5812/ircmj.13537]

[14] Abedi MR, Izady R. Acceptance and commitment therapy. Tehran: Jangal; 2013.
[15] Baghban Baghestan A, Aerab Sheibani Kh, Javedani Masrur. Acceptance and Commitment based therapy on disease perception and psychological capital in patients with type II diabetes. The Horizon of Medical Sciences. 2017; 23(2):135-140. [DOI:10.18869/acadpub. hms.23.2.135]

[16] Izadi R, Abedi MR. [Alleviation of obsessive symptoms in treat mentresistant obsessive-compulsive disorder using acceptance and commitment-based therapy (Persian)]. Feyz. 2013; 17(3):275-86. http://feyz. kaums.ac.ir/article-1-1963-en.html

[17] Hayes SC, Luoma JB, Bond FW, Masuda A, Lillis J. Acceptance and commitment therapy: Model, processes and outcomes. Behaviour Research and Therapy. 2006; 44(1):1-25.. [DOI:10.1016/j.brat.2005.06.006] [PMID]

[18] Folke F, Parling T. Melin L. Search results for Acceptance and Commitment Therapy for depression: A preliminary randomized clinical trial for unemployed on long-term sick leave. Cognitive and Behavioral Practice. 2012; 19(4):517-25. [DOI:10.1016/j.cbpra.2012.01.002]

[19] Orsillo SM, Batten SV. Acceptance and Commitment Therapy in the treatment of posttraumatic stress disorder. Behavior Modification. 2005; 29(1):95-129. [DOI:10.1177/0145445504270876] [PMID]

[20] Irandoost F, Neshat doost H T, Nadi M A, Safary S. The effectiveness of Acceptance and Commitment Therapy (ACT) on the rate of chronic pain and pain catastrophizing in women with chronic low back pain. Journal of Research in Psychological Health. 2014; 8(3):31-40. http://rph.khu. ac.ir/article-1-2226-en.html

[21] Hulbert-Williams NJ, Storey L, Wilson KG. Psychological interventions for patients with cancer: psychological flexibility and the potential utility of Acceptance and Commitment Therapy. European Journal of Cancer Care. 2015; 24(1):15-27. [DOI:10.1111/ecc.12223] [PMID]

[22] Izadi R, Abedi MR. [Alleviation of obsessive symptoms in treat mentresistant obsessive-compulsive disorder using acceptance and commitment-based therapy (Persian)]. Feyz: (Journal of Kashan University of Medical Sciences). 2013; 17(3):275-86. http://feyz.kaums.ac.ir/article1-1963-en.html

[23] Parsa M, Sabahi P, Mohammadifar MA. [The effectiveness of ac ceptance and commitment group therapy on anxiety and depression in women with MS who were referred to the MS association (Persian)]. Journal of Clinical Psychology. 2014; 6(1):29-38. [DOI:10.22075/ JCP.2018.11686.1156]

[24] Hor M, Aghaei A, Abedi A, Attari A. [The effectiveness of acceptance and commitment therapy on depression in patients with type 2 diabetes (Persian)]. Journal of Research in Behavioural Sciences. 2013; 11(2):121-8. https://www.sid.ir/en/Journal/ViewPaper. aspx?!D=338209

[25] Behrouz B. [The effectiveness of group-based acceptance and commitment therapy on post-traumatic stress disorder, coping styles, and self-efficacy in girls with abnormal grief (Persian)]. Journal of Clinical Psychology. 2016; 7(28):81-91. https://www.sid.ir/en/journal/ViewPaper. aspx?ID=532986

[26] Mohammadi Khashouei M, Ghorbani M, Tabatabaei F. The Effectiveness of Acceptance and Commitment Therapy (ACT) on Self-Efficacy, Perceived Stress and Resiliency in Type II Diabetes Patients. Global Journal of Health Science. 2017; 9(5):18-26. [DOI:10.5539/gjhs.v9n5p18]

[27] Tavakolizadeh J, Kianmehr M, Basiri Moghadam M, Pahlavan M. Effect of guided visualization on anxiety of patients with acute coronary syndrome admitted to the cardiac intensive care unit. The Horizon of Medical Sciences. 2015; 21(3):147-53. [DOI:10.18869/acadpub. hms.21.3.147] 
[28] Hoffman BM, Papas RK, Chatkoff DK, Kerns RD. Metaanalysis of psychological interventions for chronic low back pain. Health Psychology. 2007; 26(1):1-9. [DOI:10.1037/0278-6133.26.1.1] [PMID]

[29] Man LS. Systematic review and meta-analysis. Journal of the Canadian Academy of Child and Adolescent Psychiatry. 2011; 20(1):57-9. https:// www.ncbi.nlm.nih.gov/pmc/articles/PMC3024725/

[30] Vowles KE, McCracken LM. Acceptance and values based action in chronic pain: A study of treatment effectiveness and process. Journal of Consulting and Clinical Psychology. 2008; 76(3):397-407. [DOI:10.1037/0022-006X.76.3.397] [PMID]

[31] Antall GF, Kresevic D. The use of guided imagery to manage pain in an elderly orthopedic population. Orthopaedic Nursing. 2004; 23(5):33540. [DOI:10.1097/00006416-200409000-00012] [PMID]

[32] Rees BL. Effect of relaxation with guided imagery on anxiety, depression, and self-esteem in primiparas. Journal of Holistic Nursing. 2005; 13(3):255-67. [DOI:10.1177/089801019501300307] [PMID]

[33] Samani S, Jokar B, Sahragard N. Effects of Resilience on Mental Health and Life Satisfaction. Iranian Journal of Psychiatry and Clinical Psychology. 2007; 13(3):290-5. http://ijpcp.iums.ac.ir/article-1-275-en.html

[34] Christakou A, Zervas Y. The effectiveness of imagery on pain, edema, and range of motion in athletes with a grade II ankle sprain. Physical Therapy in Sport. 2007; 8(3):130-40. [DOI:10.1016/j.ptsp.2007.03.005]

[35] Bassampoor SS. [The effect of relaxation techniques on anxity of patients with myocardial inferction (Persian)]. Qazvin University of Medical Sciences. 2018; 9(35):53-8. https://www.semanticscholar.org/paper/ The-effect-of-relaxation-techniques-on-anxiety-of-Bassampoor/8638b4 47695e3ba0d924ab73fe5a0d42b89ac15b

[36] Borg W, Gall M, Gall J. Quantitative and qualitative research methods in Psychology [AR. Nasr, HR. Areyzi, M. Abolqasemi, MJ. Pakseresht, AR. Kiamanesh, Kh. Bagheri, et al, Persian trans]. Tehran: Samt Publication; 2015.

[37] Ali Far E, Nokani M. Effectiveness of Guided Visualization and Mental Imagery in Decreasing the Symptoms of Depression and Increasing Hopefulness among Hemodialysis Patients. Thought \& Behavior in Clinical Psychology. 2013: 7(27):81-90. http://jtbcp.riau.ac.ir/article_17_acbe348a476ca07719320a52a9d547ad.pdf

[38] Hayes SC, Strosahl KD. A practical guide to acceptance and commitment therapy [A. Khamseh Trans]. Tehran: Arjmand; 2004. [DOI:10.1007/978-0-387-23369-7]

[39] Besharat MA. Reliability and Validity of the 28-item Form of Mental Health Scale in Iranian Population. Journal of Legal Medicine. 2009; 5(4):91-87. https://www.researchgate.net/publication/285799823_Reliability_and_validity_of_a_short_form_of_the_mental_health_inventory_in_an_Iranian_population

[40] Sirkin Martin A, Distelberg B, Palmer BW, Jeste DV. Development of a new multidimensional individual and interpersonal resilience measure for older adults. Journal Aging \& Mental Health. 2014; 19:32-45. [DOI:1 0.1080/13607863.2014.909383] [PMID] [PMCID]

[41] Besharat MA, Ramesh S. Prediction of Severity of Cardiovascular Disease based on Resilience, Spiritual Well-being and Social Support. journal of The Ministry of Health and Medical Education. 2018; 27(1):34-45. http://www.tebvatazkiye.ir/article_81894_en.html

[42] Molina Y, Jean C, Martinez J, Reding K, Joyce P, Rosenberg A. Resilience among patients across the cancer continuum:Diverse perspective. Clinical Journal of Oncology Nursing. 2014; 18(1):93-191. [DOI:10.1188/14. CJON.93-101] [PMID] [PMCID]
[43] Ghorbani Amir H A, Moradi O, Arefi M, Ahmadian H. The Effectiveness of Acceptance and Commitment-Based Training (ACT) on CognitiveEmotional Regulation, Resiliency, and Self-Control Strategies in Divorced Women. Avicenna Journal of Neuro Psycho Physiology. 2019; 6(4):195202. [DOI:10.32598/ajnpp.6.4.5]

[44] Ghomian S, Shairi M. The Effectiveness of acceptance and commitment therapy for children with chronic pain on the function of 7 to 12 year-old. International Journal of Pediatrics. 2014; 2(7):3-1. [DOI:10.22038/IJP.2014.2569]

[45] Rahimian Buger E. [Risk Factors of cardiovascular disease in diabetes melitus type 2: Predictor role of psychologic, social and characters of disease factors (Persian)]. Prin of Psycho Hygiene. 2012; 13(3):278-94. http://ensani.ir/file/download/article/20121212101938-9434-16.pdf

[46] Momeni KH, Jalili Z, Mohseni R, Karami J, Saeedi M, Ahmadi SM. [Efficacy of teaching resiliency on symptoms reduction on anxiety of adolescence with heart disease (Persian)]. Journal of Clinical Research in Paramedical Sciences. 2015; 4(2):112-9. http://jdn.zbmu.ac.ir/article1-202-fa.pdf

[47] Fazeli Kebria M, Hasanzadeh R, Mirzaeian B, Khjevand Khosheli A. [The effectiveness of acceptance and commitment group therapy on psychological capital in cardiovascular patients in Babol (Persian)]. Journal of Babol University of Medical Sciences. 2018; 20(4):68-73. http://jbums. org/article-1-7320-fa.html

[48] DoustdarTousi S A, Golshani S. [Effect of resilience in patients hospitalized with cardiovascular diseases (Persian)]. Journal of Mazandaran University of Medical Sciences. 2014; 24(116):102-9. http://jmums.mazums.ac.ir/article-1-4252-fa.html

[49] Forbes D, Lockwood E, Elhai JD, Creamer M, O'Donnell M, Bryant R, et al. An examination of the structure of posttraumatic stress disorder in relation to the anxiety and depressive disorders. Journal of Affective Disorders. 2011; 132(1-2):165-72. [DOI:10.1016/j.jad.2011.02.011] [PMID]

[50] Yekta O, Babapour J. The effect of mental imagery on reducing depression and anxiety in children with cancer. $6^{\text {th }}$ Congress of the Iranian Psychological Association; 2017 Nov 23-25; Tehran, Iran. https://www. civilica.com/Paper-CIPSA06-CIPSA06_164

[51] Tayyari-Kalajahi B, Panah-Ali A. [The Effectiveness of Mental Imagery in Reducing Anxiety and Increasing Happiness among Heart Surgery Patients (Persian)]. Depiction of Health. 2016; 6(4):40-8. https://doh. tbzmed.ac.ir/Article/doh-138

[52] Hollier JM, Vaughan AO, Liu Y, van Tilburg MA, Shulman RJ, Thompson DI. Maternal and child acceptability of a proposed guided imagery therapy mobile app designed to treat functional abdominal pain disordersin children: Mixed-methods predevelopment formative research. JMIRPediatrics and Parenting. 2018; 1(1):e6. [DOI:10.2196/pediatrics.8535] [PMID] [PMCID]

[53] Menzies V, Taylor AG, Bourguignon C. The effect of Guided imagery on outcome of pain, functional status, andself -efficacy in persons diagnosed with fibro my logia. Journal of Alternative \& Complementary Medicin. 2006; 12(1):23-30. [DOI:10.1089/acm.2006.12.23] [PMID] [PMCID]

[54] Penzien DB, Andrasik F, Freidenberg BM, Houle TT, Lake AE, Lipchik GL, et al. Guidelines for trials of behavioral treatments for recurrent headache, first edition: American Headache Society Behavioral Clinical Trials Workgroup. American Headache Society Behavioral Clinical Trials Workgroup. Headache. 2005; 45(Suppl 2):S110-32. [DOI:10.1111/j.15264610.2005.4502004.x] [PMID]

[55] Abdoli S, Rahzani K, Safaie M, Sattari A. A randomized control trial: The effect of guided imagery with tape and perceived happy memory on 
chronic tension type headache. Scandinavian Journal of Caring Sciences. 2012; 26(2):254-61. [DOI:10.1111/j.1471-6712.2011.00926.x] [PMID]

[56] Hayes SC, Masuda A, Bissett RT, Luoma J, Guerrero LF. DBT, FAP and ACT: How empirically oriented are the new behavior therapy technologies? Behavior Therapy. 2004; 35(1):35-54. [DOI:10.1016/500057894(04)80003-0]

[57] Hart J. Guided imagery. Alternative and Complementary Therapies. 2008; 14(6):295-9. [DOI:10.1089/act.2008.14604]

[58] King K. A Review of the Effects of Guided Imagery on Cancer Patients with Pain. Complementary Health Practice Review. 2010; 15(2):98-107. [DOI:10.1177\%2F1533210110388113]

[59] Özü Ö. Guided imagery as a psychotherapeutic mind-body intervention in health psychology: A brief review of efficacy research. Europe's Journal of Psychology. 2010; 6(4):227-37. [DOI:10.5964/ejop.v6i4.232] 
This Page Intentionally Left Blank 